\title{
AS ÂNFORAS DO TEATRO ROMANO DE OLISIPO (LISBOA, PORTUGAL): CAMPANHAS 2001-2006
}

\author{
AMPHORAE FROM THE ROMAN THEATRE OF OLISIPO \\ (LISBON, PORTUGAL): 2001-2006 CAMPAIGNS
}

\author{
VICTOR FILIPE*
}

Resumo: O texto que se dá à estampa consiste no estudo das ânforas romanas exumadas nas intervenções arqueológicas realizadas no teatro romano de Lisboa nas campanhas de 2001, 2005 e 2006. Trata-se de um conjunto relativamente amplo e tipologicamente diversificado recolhido em contextos arqueológicos relacionados com a edificação e remodelação do edifício. Estes contentores testemunham, em Olisipo, a importação de produtos alimentares de vários locais do império desde meados do século II a.C. até ao terceiro quartel do século I d.C., constituindo-se como importantes indicadores para o estudo da dinâmica comercial de Olisipo.

Palavras chave: Teatro romano, Olisipo, ânforas, comércio, produtos alimentares.

\section{INTRODUÇÃO}

O estudo que aqui se apresenta corresponde a um trabalho desenvolvido em 2008 no âmbito da dissertação de Mestrado em Pré-História e Arqueologia, apresentado pelo autor à Faculdade de Letras da Universidade de Lisboa, versando sobre as ânforas de Época Romana documentadas nas intervenções

* Bolseiro de Doutoramento em Arqueologia: UNIARQ (Centro de Arqueologia da Universidade de Lisboa), FCT (Fundação para a Ciência e a Tecnologia). Correo-e: victor.filipe7@gmail.com

\begin{abstract}
This text consists in the study of the Roman amphorae recovered in the archaeological excavations accomplished in the Roman theatre of Lisbon in the 2001, 2005 and 2006 campaigns. It is a relatively wide and typologically diversified set, collected in archaeological contexts related with the construction and remodelling of the theatre. These containers testify, in Olisipo, the importation of alimentary products from several places of the empire from the middle of the 2 nd century B.C. to the third quarter of the 1 st century A.D., representing important indicators for the study of the commercial dynamics of Olisipo.

Keywords: Roman theatre, Olisipo, amphorae, trade, alimentary products.
\end{abstract}

arqueológicas levadas a cabo no Teatro Romano de Lisboa em 2001, 2005 e 2006.

Desde logo, o desenvolvimento deste tema revestia-se de alguns aspectos que se consideraram pertinentes e, simultaneamente, aliciantes: a existência de um conjunto expressivo e diversificado de materiais anfóricos provenientes de escavações recentes e com contextos bem definidos, permitindo uma leitura das diacronias e sincronias; o facto destes contextos se reportarem a um período histórico relativamente curto e bem definido no tempo - do principado de Augusto ao de Nero -, sobre o qual a informação se mantém assaz 
escassa na cidade de Olisipo, especialmente no que se refere à dinâmica comercial e dieta alimentar; por fim, a associação desta realidade arqueológica aos momentos de construção e remodelação do teatro romano de Lisboa.

Tendo em conta as especificidades da amostra, optou-se por estruturar o trabalho em três partes. Na primeira, apresenta-se o suporte estático do território no contexto geográfico do vale do Tejo e fachada atlântica e sintetiza-se a evolução histórica de Olisipo até à época de construção do teatro. Paralelamente realiza-se um breve resumo das intervenções recentes levadas a efeito no teatro romano de Lisboa, apresentando-se os contextos arqueológicos e as leituras estratigráficas, procurando-se estabelecer um faseamento diacrónico através das sincronias documentadas e a sua associação e interpretação com os momentos de construção e remodelação do edifício público.

Seguidamente, privilegiando-se os vários aspectos relacionados com a morfologia, tipologia, cronologia, conteúdo e âmbitos de produção e difusão apresentam-se e caracterizam-se sumariamente as tipologias identificadas, procurando-se determinar as distintas áreas de proveniência.

Por fim, analisam-se os dados quanto ao seu significado quantitativo e qualitativo, e determinam-se as várias leituras e apreciações possíveis, procurando integrá-las no estudo da economia antiga de Olisipo.

Refira-se ainda que o texto que agora se publica foi, como já se mencionou, redigido em 2008, tendo-se aqui optado por não realizar uma actualização do mesmo, com excepção da revisão de um ou outro pormenor. Embora o referido texto se mantenha genericamente actual, há naturalmente algumas questões que aqui se abordam que conheceram algum desenvolvimento desde então (para além, naturalmente, das questões que pouco mais representam - para este estudo, claro está - que meros "pontos no mapa"). Tal é o caso, por exemplo, da questão das ânforas ovoides produzidas no vale do Guadalquivir, que foram recentemente sistematizadas no trabalho monográfico de Rui Almeida (2008) e num extenso artigo por García Vargas, Rui de Almeida e González Cesteros (2011). Ainda assim, e independentemente da elevada qualidade dos referidos trabalhos e do seu relevante contributo para o estudo daquelas produções, considera-se que esses resultados não alteram significativamente as leituras que então foram feitas acerca das dinâmicas comerciais e hábitos de consumo na cidade de Olisipo, a partir do estudo do conjunto anfórico do teatro romano de Lisboa. (Figura 1)

\section{O VALE DO TEJO, OLISIPO E O TEATRO ROMANO}

\subsection{O vale do Tejo}

O primitivo núcleo urbano de Lisboa desenvolveu-se na colina onde hoje se implanta o castelo de São Jorge, à entrada do Tejo, junto a um antigo esteiro de rio onde desaguavam várias ribeiras. Ladeada a Oeste pelo esteiro de rio e a Sul pelo próprio Tejo, o sopé da colina do castelo reunia excelentes condições portuárias, que, aliás, viriam a estar na origem do seu crescimento e desenvolvimento. A Norte, sobressaem colinas calcárias e montes vulcânicos flanqueados por pequenas linhas de água, onde se exploravam os ricos vales aluviais caracterizados por uma agricultura rica e variada (Gaspar 1994: 12). Acerca da geografia dos arredores de Lisboa, Orlando Ribeiro faz a seguinte descrição: «...os barros basálticos dão campos limpos e abertos destinados à cultura do cereal; os calcários secundários, charnecas abandonadas ao mato e pasto; os calcários terciários cobrem-se de olivedo; as baixas argilosas, de hortas regadas; o pinhal reveste as colinas de arenito improdutivo» (Ribeiro 1998: 154).

$\mathrm{O}$ rio Tejo, verdadeira estrada de acesso ao interior, regulou e moldou, desde tempos antigos, o desenvolvimento da urbe que se fixou à entrada do seu estuário, fornecendo-lhe uma importância estratégica ímpar que ainda nos dias de hoje mantém. Esta imensa via fluvial permitiu que desde cedo se estabelecesse o contacto entre os povos da bacia mediterrânica e aqueles que habitavam as regiões do interior a montante da sua foz, fomentando, assim, importantes intercâmbios culturais e comerciais.

As particularidades topográficas do local onde se implanta a actual cidade de Lisboa permitiam um amplo controlo visual da região envolvente, principalmente da entrada do rio e do seu acesso ao interior, bem como da margem Sul, aliada a excelentes condições naturais de defesa.

Outros factores houve, decorrentes da sua localização geográfica específica, que potenciaram o seu desenvolvimento económico e lhe concederam o estatuto de importante centro urbano desde o primeiro milénio a.C. A riqueza aurífera das areias do Tejo era bem conhecida na antiguidade e aparece referida nas fontes clássicas (Plínio-o-Velho, 4, 115), do mesmo modo, aliás, que é referida a abundância de pescado (Estrabão, III, $3,1)$. As actividades directa e indirectamente relacionadas com a exploração dos recursos marinhos e fluviais pautaram, em grande medida, a economia de Olisipo, 


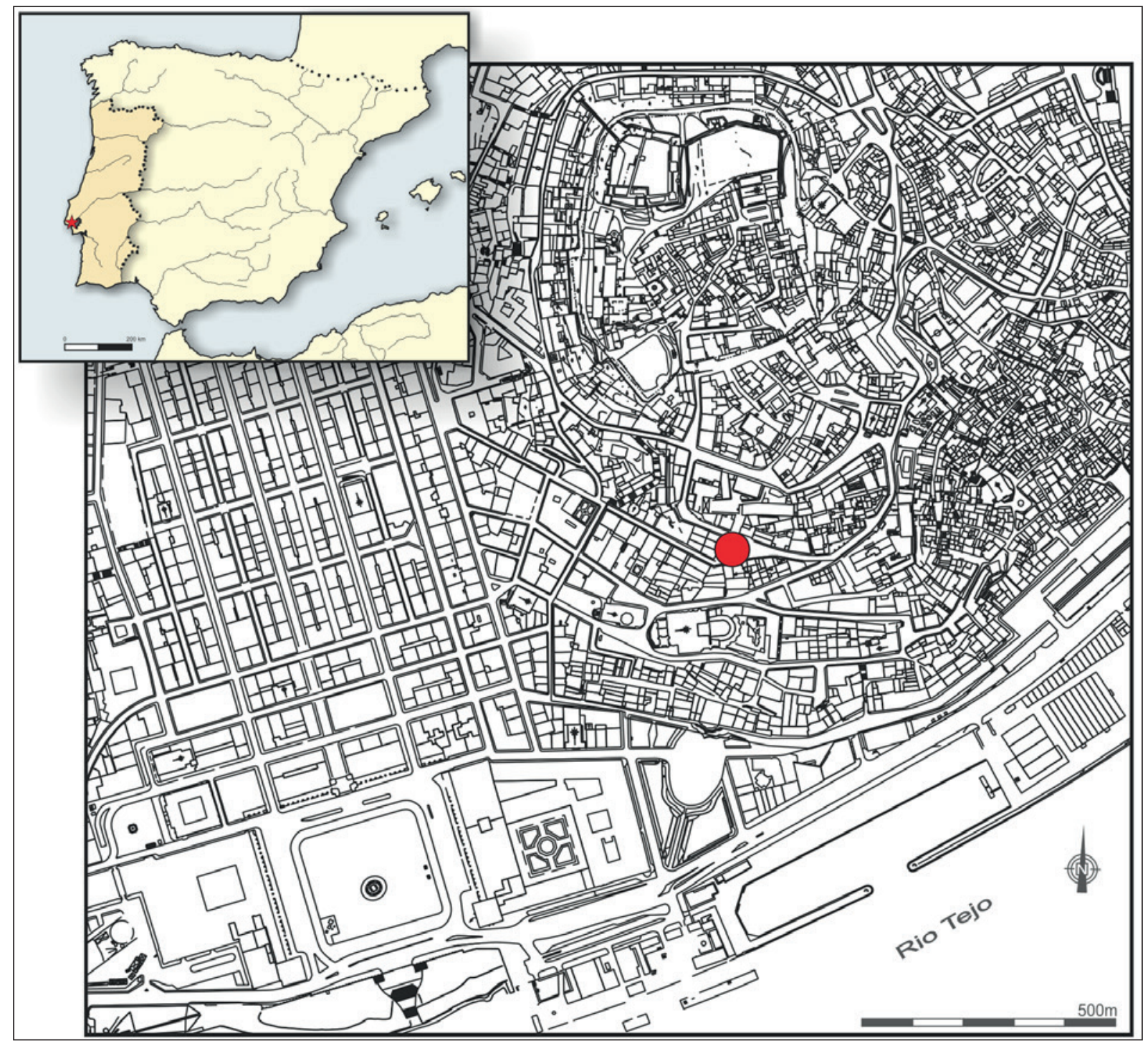

Figura 1. Localização do teatro romano na planta de Lisboa e da cidade na Península Ibérica.

dando origem a importantes indústrias de transformação do pescado, de fabrico e produção de envases cerâmicos e de exploração do sal, factores que viriam a dotar este centro urbano de uma forte componente industrial, particularmente vocacionada para a transacção de produtos piscícolas.

Estrabão descreve de forma algo curta e concisa a região da foz e do vale do Tejo, mas fá-lo de forma eloquente:

O Tejo, na foz, tem cerca de vinte estádios de largura, e tão grande é a sua profundidade que por ele navegam barcos de dez mil ânforas. Nas planícies que ficam a montante, forma, na maré-cheia, dois estuários que alagam uma superfície de cento e cinquenta estádios e tornam a planície navegável. No estuário, que fica mais a montante, envolve uma ilhota com uns trinta estádios de comprimento e pouco menos de largura, coberta de vegetação e de vinhas (Estrabão, III, 3, 1 - tradução de A. Espírito Santo, 2004: 412-413)

Em suma, a sua localização geográfica, entre o Norte atlântico e o Sul mediterrânico, na foz de um extenso e navegável rio, reunindo condições que lhe permitiram afirmar-se como um importante pólo de contacto cultural e comercial entre o interior, a fachada atlântica e o mar Mediterrâneo, bem como explorar quer as férteis 
terras das imediações quer a riqueza que o Tejo oferecia, granjeou-lhe a importância que desde cedo se começou a desenhar.

\subsection{Olisipo}

Embora existam vestígios de ocupações antigas na área do morro do castelo e vales circundantes, enquadráveis no Paleolítico (Muralha 1988), no Neolítico Antigo, Calcolítico e Idade do Bronze (Muralha et al. 2002: 246; Angelucci et al. 2004: 27), foi sobretudo a partir da Idade do Ferro que aqui se desenvolveu um centro urbano de dimensão considerável.

Os vestígios conhecidos para este período permitem esboçar um quadro do que terá sido a ocupação sidérica de Lisboa, alicerçados, principalmente, nos dados das intervenções arqueológicas levadas a cabo nos últimos vinte anos. Os resultados dessas intervenções, desenvolvidas na área do primitivo núcleo urbano de Olisipo, têm vindo sucessivamente a confirmar as considerações que Ana Margarida Arruda (2002) teceu em relação ao povoado da Idade do Ferro que terá existido em Lisboa. Entrevê-se um povoado de grandes dimensões, porventura o maior povoado orientalizante do território actualmente português, «... de importancia capital y una población probablemente muy numerosa.» (Arruda 2002: 129), o que, aliás, vem de encontro ao que Estrabão (III, 3, 1) relatou, afirmando que Olisipo era uma das duas cidades mais importantes do vale do Tejo. De facto, os dados disponíveis deixam perceber que a área ocupada abrangia o topo da colina do castelo e as suas encostas até ao rio Tejo, a Sul, ao esteiro de rio, a Oeste, na actual Baixa, e até à actual Rua da Regueira, Alfama, a Este, onde corria um pequeno curso de água, cristalizado na toponímia da cidade no nome da rua.

Ainda segundo Ana Margarida Arruda, Olisipo poderá ter representado, na gestão do território envolvente, um papel relevante, "...não podendo descartar-se a hipótese de se estar perante o sitio que, ao coordenar as actividades comerciais e de gestão dos recursos, assumiria o papel de "Lugar Central".» (Arruda et al. 2000: 29).

Mercê de condicionalismos próprios da investigação, os vestígios conhecidos atribuíveis a uma primeira fase da ocupação sidérica de Lisboa, com claras influências orientalizantes e conjuntos artefactuais de carácter marcadamente mediterrânico, são em maior número que aqueles que se reportam à fase subsequente. Os dados arqueológicos da Rua de São João da Praça (Pimenta et al. 2005), do Palácio do Marquês de Angeja (Filipe et al. 2005) e do castelo de São Jorge (Pimenta 2005), vêm contribuir para um avolumar de informação demonstrativo daquilo que Ana Margarida Arruda intitulou de "conservadorismo orientalizante» (Arruda 2002: 258), evidenciando uma continuidade cultural, contrariamente ao que acontece em outras regiões do interior, verificável quer na importação de produtos alimentares envasados em contentores anfóricos de proveniência meridional, quer de cerâmica grega de verniz negro e figuras vermelhas (Pimenta 2005), muito provavelmente igualmente difundida no ocidente peninsular pelos mercadores daquela região.

Dentro dos locais intervencionados que têm contribuído para o que hoje se conhece acerca da ocupação sidérica de Olisipo poder-se-ão referir, entre outros, o claustro da Sé de Lisboa, com ocupação pelo menos desde o século VI a.C. (Amaro 1993; Arruda et al. 2000; Arruda 2002); o Núcleo Arqueológico da Rua dos Correeiros, séculos V a III a.C. (Amaro 1995; Bugalhão 2001); a zona da alcáçova islâmica do castelo de São Jorge, onde se registaram contextos estratigráficos bem preservados com uma diacronia de ocupação que abrange grande parte do I milénio a.C., desde o século VII até à chegada dos primeiros contingentes militares romanos no terceiro quartel do século II a.C. (Gomes et al. 2003; Pimenta 2005); a Rua de São Mamede (Silva et al. 2005); o Palácio do Marquês de Angeja, com uma diacronia de ocupação compreendida entre o século VII a.C. e a romanização (Filipe et al. 2014); a Rua São João da Praça (Pimenta et al. 2005); e a Casa dos Bicos (Amaro 2002).

Em relação ao topónimo pré-romano, Olisipo, que nos é transmitido quer pelas fontes clássicas (Estrabão e Plínio-o-Velho, por exemplo) quer pela epigrafia (Silva 1944), este denuncia claras influências mediterrânicas, tendo sido sugerido que a sua origem etimológica se deveria procurar no mundo fenício (Fontes 1947). A terminação em «-ipo» relaciona-se com outros topónimos situados, sobretudo, na região da actual Andaluzia e na fachada atlântica peninsular (Fabião 1993: 143), deixando antever uma mesma realidade linguística (Guerra 2000).

Em traços largos, é este o panorama hoje conhecido para a Lisboa pré-romana, e a realidade que os romanos encontraram quando, no contexto da conquista romana da Península Ibérica, ocuparam esta região.

O palco da primeira fase das guerras travadas em solo hispânico situou-se essencialmente na zona Este e sudeste da Península Ibérica, bastante longe, portanto, da área geográfica que aqui nos ocupa. Existe, 
porém, uma referência ao ocidente peninsular no período da segunda guerra púnica (218-206 a.C.), concretamente no inverno de 210 a.C. A informação transmitida é contraditória, por um lado Políbio (10, $7,4)$ refere que Asdrúbal, filho de Giscão e chefe de exército cartaginês, invernou com o seu exército na Lusitânia, junto à foz do Tejo; por outro, Tito Lívio $(26,19,20)$ afirma que o mesmo chefe cartaginês teria invernado com o seu exército nas imediações de Cádis (Fabião 1993: 210). Ainda que a informação de Políbio esteja correcta, não deixa de ser estranho que o exército invernasse em local tão distante do palco de guerra, deixando antever, nesse caso, algum foco de instabilidade suficientemente importante para fazer deslocar, numa altura tão delicada, um exército para local tão afastado (idem: 211).

Essencialmente militar, a ocupação romana da Península Ibérica nos finais do século III e no dealbar do século II a.C. pautava-se principalmente pela exploração e pelo estabelecimento da ordem no território controlado. Em 197 a.C., a Península Ibérica é dividida em duas províncias: a Hispânia Ulterior, a ocidente, e a Hispânia Citerior a oriente, naquilo que se constituiu como a primeira divisão administrativa do território (idem: 212). Apenas com o final das "Guerras Lusitanas" (155-139 a.C.) se voltam a ter referências sobre Olisipo e o vale do Tejo nas fontes clássicas (Pimenta 2005: 24).

Embora nem sempre o registo arqueológico se consiga articular com as informações narradas pelos autores clássicos, no caso da mais antiga presença romana na cidade de Olisipo logrou-se estabelecer uma ligação entre as fontes clássicas e os dados fornecidos pela arqueologia. Estrabão, referindo-se à temerária campanha militar levada a cabo por Décimo Júnio Bruto no ocidente peninsular em 138 a.C., naquela que se constituiu como a primeira grande investida efectuada pelos contingentes militares romanos nesta zona da Península Ibérica, referiu-se a Olisipo nos seguintes moldes:

Para montante de Móron o curso navegável é ainda mais longo. Servindo-se desta cidade como base de operações, Bruto, cognominado o Calaico, atacou os Lusitanos e submeteu-os. Fortificou Lisboa para dominar o curso do rio e, deste modo, manter livre a navegação fluvial e o transporte de abastecimentos, a tal ponto estas eram as cidades mais importantes das margens do Tejo.» (Estrabão, III, 3, 1 - tradução A. Espírito Santo, 2004).

Integráveis neste âmbito cronológico, concretamente entre 140 e 130 a.C., são alguns contextos recentemente escavados na antiga alcáçova islâmica de Lisboa e estudados por João Pimenta (2005). O autor, embora sublinhando que os contextos são limitados quanto à percepção do tipo de ocupação que ali ocorreu, sugere, como proposta de trabalho, que se possa tratar de evidências de uma instalação militar romana (idem: 130). É inegável a importância que os dados recolhidos naquelas escavações têm para a compreensão das primeiras ocupações romanas na actual cidade de Lisboa (e ocidente peninsular), quer pela riqueza de informação que aportaram, quer pelos parcos testemunhos desta época conhecidos em outras partes da cidade. Também na Rua São João da Praça, no âmbito de uma intervenção de emergência, foram detectados contextos conservados que abrangem um arco temporal que se estende desde meados do século III a.C. até à chegada dos primeiros contingentes romanos (Pimenta et al. 2005).

Voltando à campanha militar encetada por Décimo Júnio Bruto, de acordo com as fontes, este general terá então estabelecido o seu quartel-general no vale do Tejo junto à cidade de Móron, cuja exacta localização se desconhece, não descurando, todavia, a retaguarda, tendo, através da fortificação de Olisipo, criado condições para garantir um fácil abastecimento por via marítima ao seu exército (Fabião 1993: 217). Ainda relativamente à localização de Móron, segundo Fabião (idem), há que buscá-la em três locais - Chões de Alpompé, Alpiarça (Alto do Castelo) ou Santarém, embora a primeira hipótese seja a mais consistente (Fabião 2006: 28).

O papel que o vale do Tejo terá tido no contexto das acções militares desenvolvidas por Roma no extremo ocidente peninsular não se esgota na campanha de Décimo Júnio Bruto, deixando-se entrever igualmente nas operações militares levadas a cabo por C. Júlio César, já em 61-60 a.C., contra os Lusitanos. O então Pretor da província da Ulterior estabeleceu o seu quartel-general em Scallabis e avançou para Norte recorrendo ao apoio de meios navais (Fabião 1989: 46), tendo, por certo, Olisipo desempenhado um papel activo no âmbito das actividades transversais que estas movimentações militares sempre estimulam.

Entre 31 e 27 a.C., Olisipo recebeu o estatuto de municipium civium Romanorum e, com ele, a designação de Felicitas Iulia Olisipo (Faria 1999: 37), indício evidente da importância que esta urbe detinha à época. Durante o principado de Augusto assiste-se a uma enérgica reestruturação urbanística na cidade de Olisipo, tendo então sido construídos alguns dos edifícios públicos mais emblemáticos de período romano que hoje se conhecem nesta cidade, como o teatro - que aqui 
nos ocupa - e, presumivelmente, o fórum e as termas (Alarcão 1994; Fernandes 1997; Silva 1999; Bugalhão 2001). Esta reestruturação inscreve-se num conjunto de reformas mais amplo empreendido por Augusto na Hispânia, e no restante império, constituindo-se como um testemunho do impulso urbanizador daquele que é normalmente designado como o primeiro imperador romano (Le Roux 1995; Fabião 2006).

\subsection{O teatro romano}

O teatro romano de Lisboa localiza-se na encosta Sul da colina do castelo de São Jorge, no local onde actualmente confluem as ruas da Saudade e de São Mamede. Embora de modestas dimensões, quando comparado com outros teatros romanos da mesma época, este importante equipamento de lazer da Lisboa romana evidencia-se pela excelência da sua construção e técnicas construtivas adoptadas, bem como pelo hábil e eficaz aproveitamento da topografia do terreno (Fernandes 2006: 194).

A descoberta deste edifício nos tempos modernos deve-se ao terramoto de 1755. Com efeito, foi durante as obras de reconstrução da cidade, em 1798, que ele foi identificado e desaterrado sob a orientação dos arquitectos Francisco Xavier Fabri e Manuel Caetano de Sousa.

Seria em 1964, mais de um século e meio depois de Francisco Fabri propor ao rei a salvaguarda das ruínas, que, na sequência da aquisição de alguns dos edifícios construídos sobre o teatro romano, se viriam a efectuar as primeiras intervenções arqueológicas no local. A iniciativa coube a D. Fernando de Almeida, então Presidente da Associação dos Arqueólogos Portugueses e professor na Faculdade de Letras da Universidade de Lisboa (Almeida 1966: 563; Fernandes 2007: 30).

Estas intervenções arqueológicas viriam a ter continuidade entre 1966 e 1967 sob a direcção de Irisalva Moita, na altura conservadora dos Museus Municipais da Câmara Municipal de Lisboa. A área intervencionada na década de sessenta corresponde essencialmente à zona que havia sido identificada e registada por Francisco Xavier Fabri e Manoel Caetano de Sousa nos finais do século XVIII, redescobrindo-se a zona da orchestra e o embasamento do muro do proscaenium, tendo-se ainda posto a descoberto outras estruturas, como o início dos degraus da imma cavea a Norte, e o arranque da parede Sul do aditus maximus a Este (Moita 1970: 7-37; Fernandes 2006: 182). Embora Irisalva Moita tenha continuado a desenvolver esforços no sentido de garantir a continuação das intervenções arqueológicas no local, os trabalhos viriam a ser interrompidos, por dificuldades diversas, em 1967. (Figura 2).

Entre 1985 e 1988 o Instituto Arqueológico Alemão procedeu ao levantamento gráfico exaustivo dos vestígios arqueológicos do teatro romano de Lisboa. O trabalho foi dado à estampa em 1990, juntamente com uma proposta sobre a dimensão total do monumento (Hauschild 1990: 348-392), hoje posta em causa face aos novos dados entretanto obtidos no decurso das recentes intervenções (Fernandes 2007: 30).

Data de 1987 a criação do entretanto extinto Gabinete Técnico do Teatro Romano de Lisboa, então sob a responsabilidade de Adriano Vasco Rodrigues. As intervenções arqueológicas iniciar-se-iam em 1989, sob a responsabilidade de António Dias Diogo, prolongando-se até 1993. Durante estes anos as intervenções centraram-se sobretudo na zona das bancadas, a Norte, sob a rua da Saudade, onde se exumou parte da cavea e do aditus maximus, a Este. Procedeu-se ainda ao desmonte de parte das fachadas dos edifícios da rua da Saudade, parcialmente demolidas na década de sessenta (idem: 30 e 31). Ainda durante estas campanhas, foi identificado um dos vomitoria, localizado no topo da imma cavea, então posta a descoberto, bem como um pequeno muro em pedra vã que Dias Diogo considerou particularmente importante na definição da cronologia de alteração da funcionalidade do teatro, possivelmente na segunda metade do século V (Diogo 1993: 222 e 224).

Os resultados destas campanhas viriam a ser parcialmente publicados por Dias Diogo em 1993. O mesmo autor publicaria, anos mais tarde, conjuntamente com Eurico de Sepúlveda, o estudo das lucernas provenientes das intervenções arqueológicas realizadas entre 1989 e 1993 no teatro romano (Diogo e Sepúlveda 2000: 153-161), bem como o estudo das ânforas aí exumadas (Diogo 2000: 163-179). (Figura 3)

Em 1998 foi desactivado o Gabinete Técnico do Teatro Romano de Lisboa e, simultaneamente, apresentado por Ana Cristina Leite (Chefe de Divisão dos Museus e Palácios do Departamento de Património Cultural da Câmara Municipal de Lisboa) um Programa de Recuperação e Valorização do Teatro Romano, que compreendia um conjunto de objectivos que englobavam: a conservação e restauro das estruturas colocadas a descoberto em anteriores intervenções e respectiva musealização; criação do Museu do Teatro Romano; intervenção arqueológica dos locais a serem afectados pelas obras para instalação do futuro museu; integração urbana e reabilitação da área envolvente (Fernandes 2007: 31). 


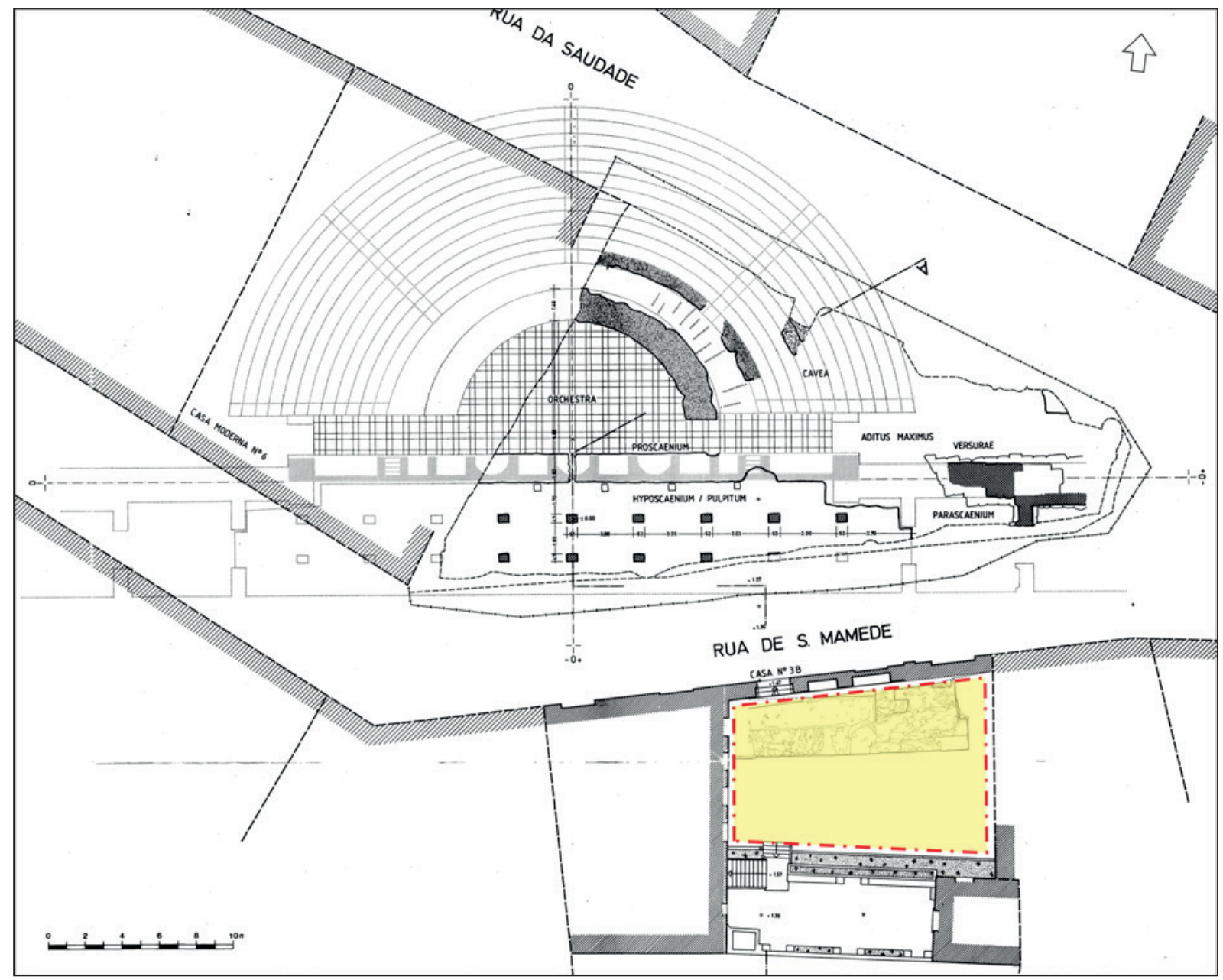

Figura 2. Levantamento e proposta de dimensão total do teatro romano de T. Hauschild (1990), e localização das intervenções arqueológicas de 2001, 2005 e 2006.

Figura 3. Aspecto geral sobre a área de escavação do pátio, observando-se em cima à esquerda o muro do postcaenium (fotografia do autor, 2012).

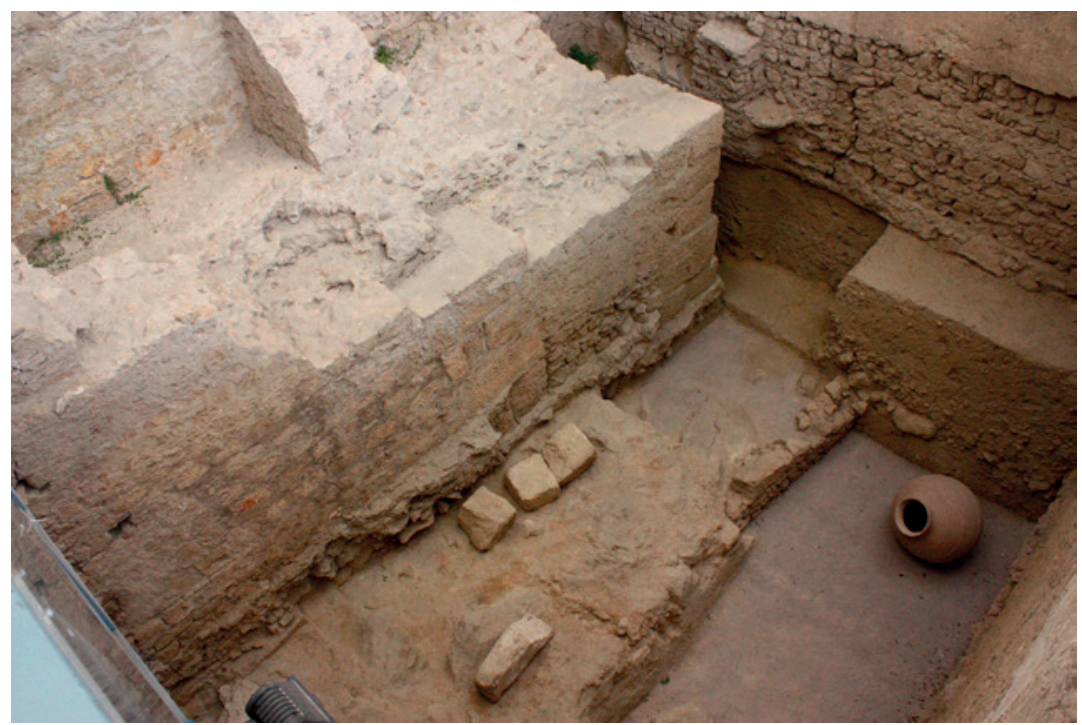


É neste projecto que se inserem as mais recentes intervenções arqueológicas levadas a cabo no teatro romano de Lisboa em 2001, 2004, 2005 e 2006, sob a direcção científica de Lídia Fernandes

\section{REALIDADE ARQUEOLÓGICA E SIGNIFICADO DOS CONTEXTOS ESTRATIGRÁFICOS}

O conjunto cerâmico objecto deste estudo provém integralmente das intervenções arqueológicas levadas a cabo em 2001, 2005 e 2006 na zona localizada a Sul do teatro. Proceder-se-á aqui apenas à análise dos contextos de Época Romana documentados nas escavações de 2005 e 2006.

Nos depósitos atribuíveis ao terceiro quartel do século I d.C. regista-se sobretudo a presença de materiais tardo-republicanos e do principado de Augusto, bem como da Idade do Ferro, claramente descontextualizados, testemunhando uma ocupação ininterrupta nesta zona da cidade pelo menos desde o século VII a.C. até ao terceiro quartel do século I d.C. (Fernandes 2007: 35). A formação destes depósitos corresponde a uma acção de aterro intencional aparentemente realizada num único momento, estando certamente relacionada com as obras de remodelação do teatro romano, que se sabe terem ocorrido no ano de 57 d.C., durante o reinado de Nero, através da inscrição do frons pulpitum do proscaenium, oferecida por Caius Heius Primus, seviro augustal, que dedicou ao imperador as obras do proscaenium e da orchestra (Fernandes 2007: 35; Fernandes e Filipe 2007: 230).

A associação de cerâmicas de paredes finas datáveis do principado de Augusto e do período de Tibério a Nero, de lucernas da mesma época, de várias formas de terra sigillata itálica e sudgálica com produção genericamente balizada entre 15 a.C. e 60 d.C. (Sepúlveda e Fernandes 2009), a par da existência de ânforas de tipo Dressel 20, Verulamium 1908 e algumas variantes possivelmente mais tardias de Haltern 70, aponta, como atrás se referiu, para uma cronologia coincidente com a data de remodelação do teatro, isto é, 57 d.C., ou, eventualmente, para um momento posterior não muito distante.

Nos níveis mais antigos em que foram recolhidas ânforas romanas - camada 24 da vala 11 , camada 16 das valas 9 e 11 e camada 11 da vala 10 - regista-se a presença de Greco-Itálicas, Dressel 1 Itálicas, Lamboglia 2 e Mañá C2 (T-7.4.3.3.) a par de um fragmento de cerâmica de engobe vermelho pompeiano da forma 6 de Aguarod Otal (1991), produzida a partir de Augusto, e de terra sigillata itálica com produção atestada a partir de 27 a.C. Estes depósitos encostam à base do muro do postcaenium e correspondem a um aterro presumivelmente efectuado num momento imediatamente após a construção da referida estrutura, sendo, portanto, coevos da construção daquele importante equipamento de lazer da cidade de Olisipo.

A existência dos supracitados níveis de aterro de época romana parece encontrar explicação na construção de uma plataforma nivelada entre o muro do postcaenium e o paredão que delimita o espaço a Sul, igualmente construído naquele período, e que permite vencer um desnível natural bastante acentuado em relação à rua Augusto Rosa, constituindo-se, assim, como um patamar artificial coetâneo da construção do teatro e perfeitamente articulado naquele conjunto edificado (Fernandes 2007: 35).

Nas camadas 12a, 18, 11a, 18b, 20 e 22 da vala 11, e 13 da vala 10, que se sobrepõem aos depósitos anteriormente descritos, observa-se a associação de uma moeda de Augusto, cerâmica de engobe vermelho pompeiano e terra sigillata itálica a ânforas de tipo Greco-Itálico, Dressel 1 Itálica, Mañá C2 (T-7.4.3.3.), T-9.1.1.1., Oberaden 83, Haltern 70 e Ovóides Lusitanas, remetendo-nos, à semelhança dos níveis anteriormente referidos, para um horizonte cronológico genericamente enquadrável no principado de Augusto. (Figura 4).

Com base nas especificidades estratigráficas e nas características dos materiais cerâmicos atrás referidos, e seguindo de perto não só os dados cronológicos fornecidos pelas ânforas, mas também a cronologia de produção de algumas das tipologias de terra sigillata itálica exumadas em níveis correspondentes à remodelação do teatro, algumas das quais com produção bastante circunscrita no tempo (entre 15 a.C. e 5 d.C.; entre 1 e 15 d.C.; e outras a partir de 15 e 10 a.C.), poder-se-á propor que a construção do teatro romano terá ocorrido algures durante os primeiros quinze ou vinte anos da nossa Era, proposta que, aliás, está de acordo com aquelas que Lídia Fernandes tem apresentado com base nos estudos que tem vindo a efectuar sobre as soluções e elementos arquitectónicos utilizados neste espaço cénico (Fernandes 2006, 2007 e 2008; Sepúlveda e Fernandes 2009).

Assim, relativamente ao período romano, e perante os dados anteriormente expostos, poder-se-ão estabelecer duas fases cronológicas distintas para os contextos preservados:

- Fase 1: Enquadrável nos finais do principado de Augusto/inícios de Tibério e coetânea da construção do teatro romano. Verifica-se a associação de ânforas Greco-Itálicas, Mañá C2 (T-7.4.3.3.), T-9.1.1.1., 


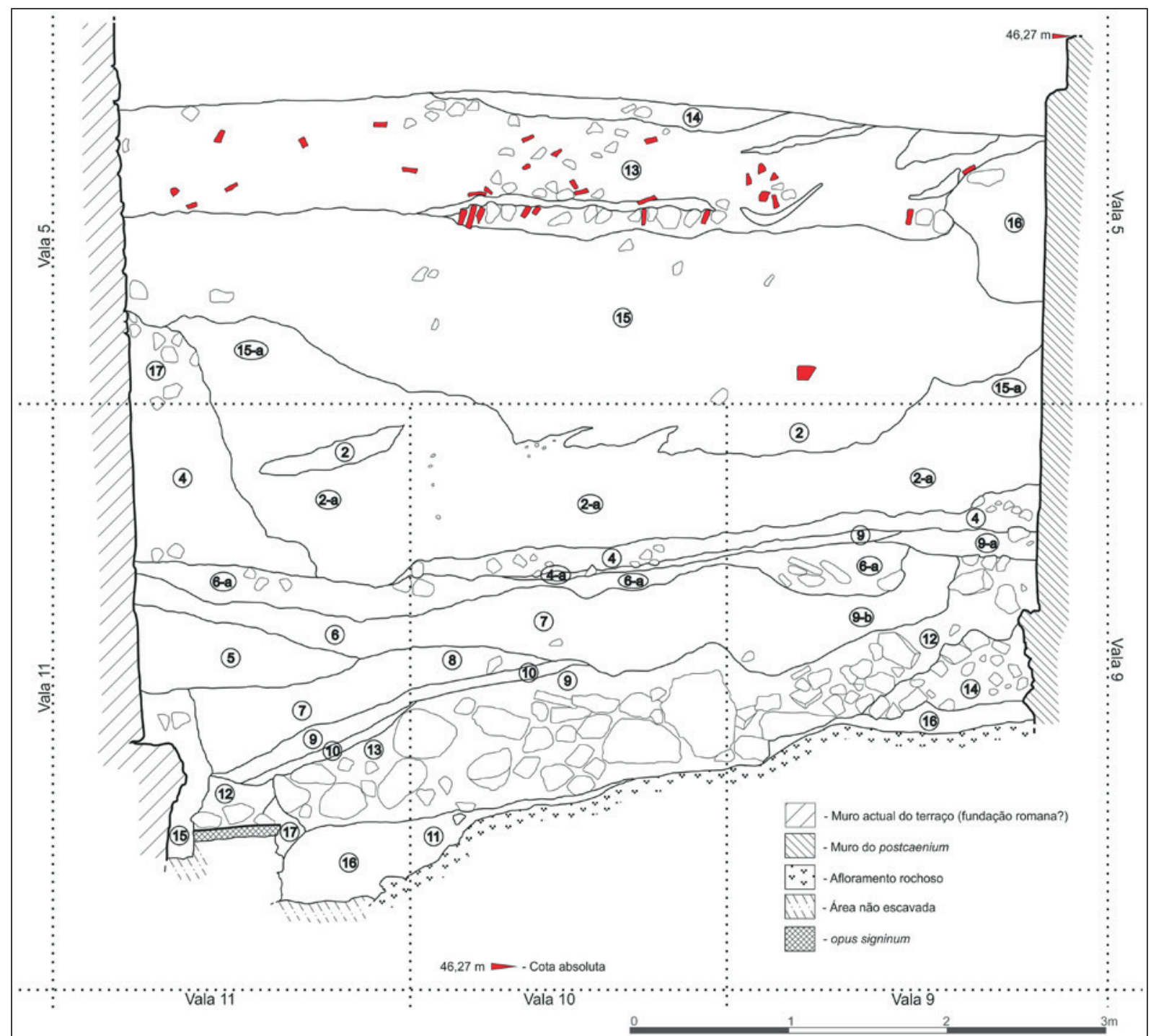

Figura 4. Perfil estratigráfico a Oeste do pátio (modificado a partir de Fernandes e Filipe 2007).

Dressel 1, Lamboglia 2, Oberaden 83, Haltern 70 e Ovóides Lusitanas, juntamente com terra sigillata itálica com produção atestada a partir de 27 a.C., cerâmica de engobe vermelho pompeiano - forma 6 de Aguarod Otal (1991) - e uma moeda de Augusto. A presença de numerosos materiais do período de Augusto nos contextos da fase seguinte sublinha a existência de uma intensa ocupação deste espaço durante esta primeira fase, da mesma forma que demonstra terem existido, posteriormente, grandes perturbações nos níveis precedentes.

- Fase 2: Traduz-se num conjunto de depósitos integrantes de um aterro que terá, presumivelmente, ocorrido durante um curto espaço de tempo, relacionando-se directamente com as obras de remodelação do teatro, realizadas no ano de 57 d.C.. Para além de inúmeros materiais de cronologias mais antigas, que se estendem diacronicamente desde a Idade do Ferro até à primeira metade do século I d.C., constata-se a presença de ânforas cronologicamente enquadráveis no segundo e terceiro quartéis do século I d.C., de tipo Dressel 20, Verulamium 1908 e algumas variantes tardias de Haltern 70, tal como de cerâmicas de paredes finas datáveis do período de Tibério a Nero, de terra sigillata sudgálica da mesma época, de terra sigillata itálica produzida durante a primeira metade do século I até ao ano 60 do mesmo século, e de lucernas de período idêntico. 
Embora se possa estabelecer como baliza cronológica para a formação destes depósitos o período entre o início e o fim do principado de Nero, ela deverá ter ocorrido durante as obras de remodelação do espaço cénico ou, quanto muito, nos anos imediatamente seguintes.

\section{AS ÂNFORAS DO TEATRO ROMANO DE LISBOA}

\subsection{Amostra e pressupostos metodológicos}

No conjunto dos materiais exumados durante as intervenções arqueológicas levadas a efeito no teatro durante as campanhas de 2001, 2005 e 2006 foram identificados e seleccionados 532 fragmentos classificáveis de ânfora, a que correspondem 209 bordos, 247 asas e 76 fundos, atribuíveis a 19 tipologias distintas, traduzindo-se num Número Mínimo de 211 Indivíduos (NMI), acrescentando-se ainda um conjunto de 44 opérculos.

Genericamente, realizou-se uma análise qualitativa e quantitativa do conjunto anfórico, privilegiando-se a leitura possível das diacronias e sincronias evidenciadas pelos contextos de época romana, a que se acrescentou, numa perspectiva mais ampla de interpretação histórica, os dados da quantificação, devidamente relativizados.

Os diferentes tipos anfóricos foram organizados por conteúdo em quatro grupos distintos - vinho, azeite, preparados piscícolas e outros produtos - e, dentro de cada grupo, ordenados cronologicamente, do mais antigo para o mais recente.

Embora não perdendo de vista a relatividade de que se revestem os resultados obtidos através da quantificação de cerâmicas, optou-se por efectuar uma apreciação quantitativa do conjunto, considerando-se que esses dados permitem um quadro mais alargado da interpretação histórica.

Nesta perspectiva, privilegiou-se a análise por número mínimo de indivíduos (NMI) de acordo com o protocolo de quantificação de cerâmicas de Mont Beuvray (Arcelin e Tuffreau-Libre 1998), devidamente adaptado às especificidades da amostra disponível. Sob pena de adulterar o significado da amostra, não foram contabilizados os fragmentos de asa e fundo, tendo-se calculado o NMI apenas com base nos fragmentos de bordo. Esta opção deveu-se sobretudo à efectiva dificuldade em diferenciar algumas formas tipológicas, de idêntica morfologia e características petrográficas, somente a partir de fragmentos de asa ou fundo. Tal verifica-se, principalmente, entre as formas Dressel 1 Itálica e Greco-Itálica, bem como em algumas produções da região do Guadalquivir como os tipos Haltern 70, Classe 67, Dressel 12 e Classe 24.

Contudo, foi contabilizado um fragmento de fundo do tipo Richborough 527 e uma asa de tipo Dressel 2-4 de produção itálica. De facto, tendo em conta as suas características morfológicas e petrológicas, a classificação destes exemplares não oferece quaisquer dúvidas. Acresce o facto de não existir neste conjunto qualquer bordo atribuível àquelas tipologias que apresente as típicas pastas de um e outro tipo - existe um fragmento de bordo de Dressel 2-4 mas de produção bética -, considerando-se mais sensata a inclusão destes dois fragmentos no NMI do que a sua não representação.

\section{2. Ânforas vinícolas}

As ânforas vinícolas estão representadas no teatro pelas produções itálicas de tipo Greco-Itálica, Dressel 1, Lamboglia 2 e Dressel 2-4, e pelas produções da região meridional da Península Ibérica dos tipos Haltern 70, Dressel 2-4, Dressel 28, ânforas de tipo Urceus e Verulamium 1908.

Em relação às Greco-Itálicas, produzidas entre o final do século IV a.C. e o terceiro quartel do século II a.C. na Sicília e numa vasta área da Península Itálica, tanto na costa tirrénica como na adriática (Hesnard e Lemoine 1981; Hesnard et al. 1989; Cipriano e Carré 1989), a sua presença no teatro é bastante significativa, sobretudo tendo em conta que nas campanhas de 2001, 2005 e 2006 não foram escavados contextos republicanos. Foram identificados 14 exemplares de bordo da sua variante mais tardia, o que corresponde a $7 \%$ do NMI, tendo sido exumados em contextos da Época de Augusto e do terceiro quartel do século I, bem como em níveis medievais e modernos. A distinção entre as Greco-Itálicas e as primeiras produções de Dressel 1 foi feita com base na proposta metodológica de Gateau (1990).

Em Portugal a geografia da sua distribuição tem-se alargado nos últimos anos, mercê de um incremento dos estudos anfóricos e da divulgação de resultados de várias intervenções, embora esteja, muito provavelmente, ainda longe da real amplitude que a sua difusão compreendeu, facto, aliás, já devidamente realçado por C. Fabião (1998a: 372), ainda que então apenas fossem conhecidos exemplares desta forma no vale do Tejo, em Santarém e Chões de Alpompé (idem: 371). Actualmente encontram-se documentadas em Chões de Alpompé, Santarém, Porto do Sabugueiro (Muge), Vila Franca de Xira, Lisboa, Mata-Filhos (Mértola), Monte Molião (Lagos), Faro, Cerro do Cavaco e Castro Marim (Pimenta 
2005: 119; Bargão 2006: 37, fig. 16; Pimenta e Mendes 2008: 190, fig. 18), verificando-se aquilo que Carlos Fabião (1998a: 374) havia preconizado: a identificação de novos exemplares na costa algarvia e em "locais onde se documenta uma mais estreita relação com o mundo «ibero-turdetano»", como, neste caso, Mértola (Mata-Filhos). As peças recolhidas apontam invariavelmente para contextos da segunda metade do século II a.C., sendo uma constante a coexistência das Greco-Itálicas com as Dressel 1, com predomínio das últimas, e evidente o âmbito militar da sua difusão (Fabião 1998a: 374 e 375; Arruda e Almeida 1999: 32; Bargão 2006: 38).

Curiosamente, e ao contrário do que acontece na generalidade dos sítios do Ocidente peninsular, no caso do teatro romano de Lisboa verifica-se a presença de ânforas de tipo Greco-Itálico em quantidades ligeiramente superiores às da Dressel 1. Os exemplares do teatro romano provêm todos da costa tirrénica da península itálica, estando presentes alguns com as típicas pastas da Campânia.

A Dressel 1 itálica, produzida desde os meados do terceiro quartel do século II a.C. até meados da segunda metade do século I a.C. (Desbat 1998; Pimenta 2005), está representada por 11 fragmentos de bordo $(5 \%$ do NMI), essencialmente exumados em contextos romanos da Fase 1 e 2 ( 7 fragmentos), estando presentes diferentes variantes de bordo, desde as mais antigas, ou de transição, às mais tardias, típicas do século I a.C..

Esta forma conheceu uma ampla difusão nos territórios sob a alçada de Roma, principalmente no Mediterrâneo ocidental, nas costas tirrénicas de Itália, na Gália e na Hispânia (Molina Vidal 1997: 46). Em Portugal as Dressel 1 estão bem atestadas em todo o território, desde o Minho ao Algarve, no interior e no litoral, embora com particular incidência nas zonas costeiras e nas áreas próximas aos grandes rios (a geografia da sua distribuição no território actualmente português foi recentemente actualizada por João Pimenta 2005: 120, fig. 31; e Patrícia Bargão 2006: 40, fig. 17). Especificamente em Lisboa encontram-se particularmente bem documentadas no castelo de São Jorge onde foram identificados mais de duas centenas de exemplares (Pimenta 2005). As Dressel 1 deste conjunto provêm maioritariamente da região da Campânia, estando presentes também produções de outros locais da costa tirrénica. (Figura 5).

Já as Lamboglia 2 (finais do século II a.C. até ao principado de Augusto) e as Dressel 2-4 (meados da primeira centúria a.C. até aos finais do século II d.C.) de produção itálica (com as típicas pastas da Campânia), bem como as Dressel 2-4 produzidas no vale do Guadalquivir (final do século I a.C. até ao último terço do século I d.C. (Bernal Casasola et al. 2004: 643; Almeida 2008: 140), são claramente minoritárias, tendo-se documentado apenas um exemplar de cada. Em relação à Lamboglia 2, escassamente documentada em território actualmente português, a geografia da sua distribuição foi recentemente actualizada (Bargão 2006), observando-se a sua presença apenas em Chões de Alpompé, Santarém, Lisboa, Mértola, Cabo Sardão, Mesas do Castelinho, Ilhéu do Rosário, Castro Marim e Faro (idem: 42, fig. 18). Com excepção do conjunto de Mértola (Fabião 1987), que apresenta o maior grupo e em melhor estado de conservação, esta forma é normalmente minoritária nos conjuntos anfóricos. $\mathrm{O}$ exemplar do teatro romano foi produzido na costa adriática da península itálica. Quanto à Dressel 2-4 itálica, encontra-se difundida um pouco por todo o mundo romano, estando atestada no território actualmente português principalmente na faixa costeira mas também no interior.

A variante bética aparece representada sobretudo em contextos do Mediterrâneo ocidental, nomeadamente na costa levantina peninsular, na Lusitânia, na região noroeste da província da Tarraconense e na Britânia (Fabião 1998a: 180).

A escassa representatividade da Dressel 2-4 no conjunto aqui em estudo regista-se igualmente na maioria dos conjuntos anfóricos onde são reconhecidas, tanto no que diz respeito às que provêm da península itálica (que se dirigiam sobretudo aos acampamentos militares do limes germânico e da Britannia - Fabião 1989: 59) como às que foram exportadas a partir da Bética. De facto, e no que às segundas concerne, a invariável escassa presença desta forma, quer em centros produtores quer em centros consumidores, indicia tratar-se de uma produção minoritária (Fabião 1998a: 180; Almeida 2008: 142). (Figura 5).

No Teatro Romano de Lisboa recolheram-se 32 fragmentos de bordo atribuíveis ao tipo Haltern 70, o que corresponde a $15 \%$ do NMI, sendo a tipologia mais representada a seguir às produções lusitanas antigas. Trata-se de um contentor produzido no Vale do Guadalquivir entre meados do século I a.C. e finais do século I/inícios do século II d.C. (Remesal Rodríguez e Carreras Monfort 2003: 21 e 22). Não obstante a sua presença assídua em níveis tardo-republicanos, como por exemplo em Mesas do Castelinho (Fabião e Guerra 1994: 280), na Lomba do Canho (Fabião 1989: 61 a 64) e em Santarém (Almeida 2008), é a partir do principado de Augusto e durante o século I d.C. que se torna mais frequente e típica nos contextos arqueológicos. Relativamente à sua difusão, o tipo Haltern 70 foi amplamente exportado para as províncias do extremo ocidente peninsular, estando igualmente presente em 
quase todas as regiões da metade ocidental do império romano (Fabião 2000: 668). É particularmente significativa na fachada atlântica, com destaque para o noroeste da Península Ibérica, e no eixo Ródano-Reno (Morais 2004: 549; Morais e Carreras Monfort 2003: fig. 52). (Figura 6).

No território actualmente português regista-se a sua presença um pouco por todo o país, de Norte a Sul, no interior e no litoral, quer em sítios terrestres quer em meios aquáticos (Morais e Carreras Monfort 2003).

A problemática inerente aos produtos transportados por ânforas de tipo Haltern 70 tem suscitado diversas discussões, assumindo por vezes "contornos de polémica anglo-saxónica” (Fabião 2000: 668; García Vargas 2004: 507). De facto, embora tradicionalmente tida como uma ânfora vinária destinada a transportar os afamados vinhos da província da Bética na antiguidade, não existem evidências arqueológicas directas que comprovem esse conteúdo (Morais 2004: 546). Por outro lado, a existência de vários tituli picti em contentores desta tipologia tem comprovado o transporte de subprodutos como o defructum (liquido doce obtido pela cozedura do mosto), mulsum (vinho cozido misturado com mel) e sapa (vinho cozido de uso comum na cozinha), para além de oliva ex defructo (azeitonas negras em conserva) e oliva dulcis (azeitonas preservadas num produto doce derivado do vinho) (idem: 545 e 546). Todavia, tudo indica tratar-se de uma ânfora preferencialmente destinada a transportar vinho, não obstante ter sido igualmente utilizada para transportar subprodutos vínicos e conservas (Fabião 1998b: 180; Fabião 2000: 668; Tchernia 1986: 142).

A Verulamium 1908, produzida no Vale do Guadalquivir entre o segundo quartel do séc. I e meados do séc. II d.C. (Almeida 2008), está representada por 9 fragmentos de bordo, representando 4\% no NMI. Provêm sobretudo de contextos modernos e medievais, tendo-se recolhido dois exemplares em níveis da Fase 2. Em Portugal são conhecidos exemplares desta forma em Santarém, exumados em níveis atribuíveis ao último quartel do século I d.C. (idem: 71). É possível, com base nas características morfológicas e na descrição das pastas, que dois exemplares da Cividade de Âncora (n. ${ }^{\circ} 1$ da Estampa XXVII e n. ${ }^{\circ} 3$ da Estampa XXIX), classificados respectivamente como Dressel $14 \mathrm{~b}$ e Beltran VI, um outro de Monte Murado (n. ${ }^{\circ}$ 2, Estampa LXXXIII), classificado como Dressel 14b, bem como um proveniente da Cividade de Terroso (n. ${ }^{\circ}$ 5, Estampa XLIV), classificado como Dressel 2-4 (Paiva 1993), correspondam na realidade à forma Verulamium 1908. Todos eles são provenientes de níveis que se estendem desde fases anteriores à viragem da Era até meados do século I d.C. (idem).

A presença de Dressel 28 - finais do século I a.C. até à primeira metade do século II d.C. (Peacock e Williams 1986: 150) - e de uma ânfora de tipo Urceus principado de Augusto a meados do século I (Morais 2007) - no teatro é quase vestigial, verificando-se apenas um exemplar de bordo de cada. A primeira apresenta as típicas pastas da região da Bética costeira, enquanto a segunda foi seguramente produzida no vale do Guadalquivir. (Figura 7).

Foi identificada uma marca de oleiro em relevo com cartela rectangular (litteris extantibus), aplicada no arranque inferior da asa (in radice ansae), sobre uma ânfora de tipo Dressel 1 ou Greco-Itálica, produzida na costa tirrénica da península itálica. Esta estampilha não permite leitura, encontrando-se fracturada longitudinalmente na parte superior e em muito mau estado de conservação. (Figura 8).

\section{3. Ânforas oleícolas}

No que se refere às ânforas oleícolas, os dados do Teatro Romano demonstram uma clara predominância do azeite importado do Vale do Guadalquivir. A única excepção é um fragmento de bordo e um de fundo de Tripolitana Antiga, contentor produzido na região da Tripolitânia no Norte de África desde a primeira metade do século II a.C. até ao principado de Augusto (Benquet e Olmer 2002: 319 a 322). O azeite do Vale do Guadalquivir chegou sobretudo em ânforas de tipo Oberaden 83 , tendo-se contabilizado 31 fragmentos de bordo (15\% do NMI) atribuíveis a esta tipologia, sendo que 17 foram exumados em níveis Medievais e Modernos. Esta forma foi produzida entre o último terço do século I a.C. e, presumivelmente, o final do principado de Tibério (Berni Millet 1998: 30; Almeida 2008: 150). As ânforas de tipo Dressel 20 estão muito menos representadas do que aquelas, tendo sido identificados 14 fragmentos de bordo ( $7 \%$ do NMI), sendo que 7 provêm de contextos do terceiro quartel do século I e os restantes de contextos posteriores ao período romano. Estas últimas são todas de cronologia Júlio-Cláudia.

Convém referir que os exemplares que aqui se consideram como Oberaden 83 (= Classe 24) possuem as características morfológicas normalmente atribuídas aos chamados protótipos augustanos e tiberianos, e que Berni Millet (1998) classificou como tipo B, e Almeida (2008) como Ovoide 7. Porém, a indiscutível relação formal e cronológica entre esta forma e a Ovoide 6, que 


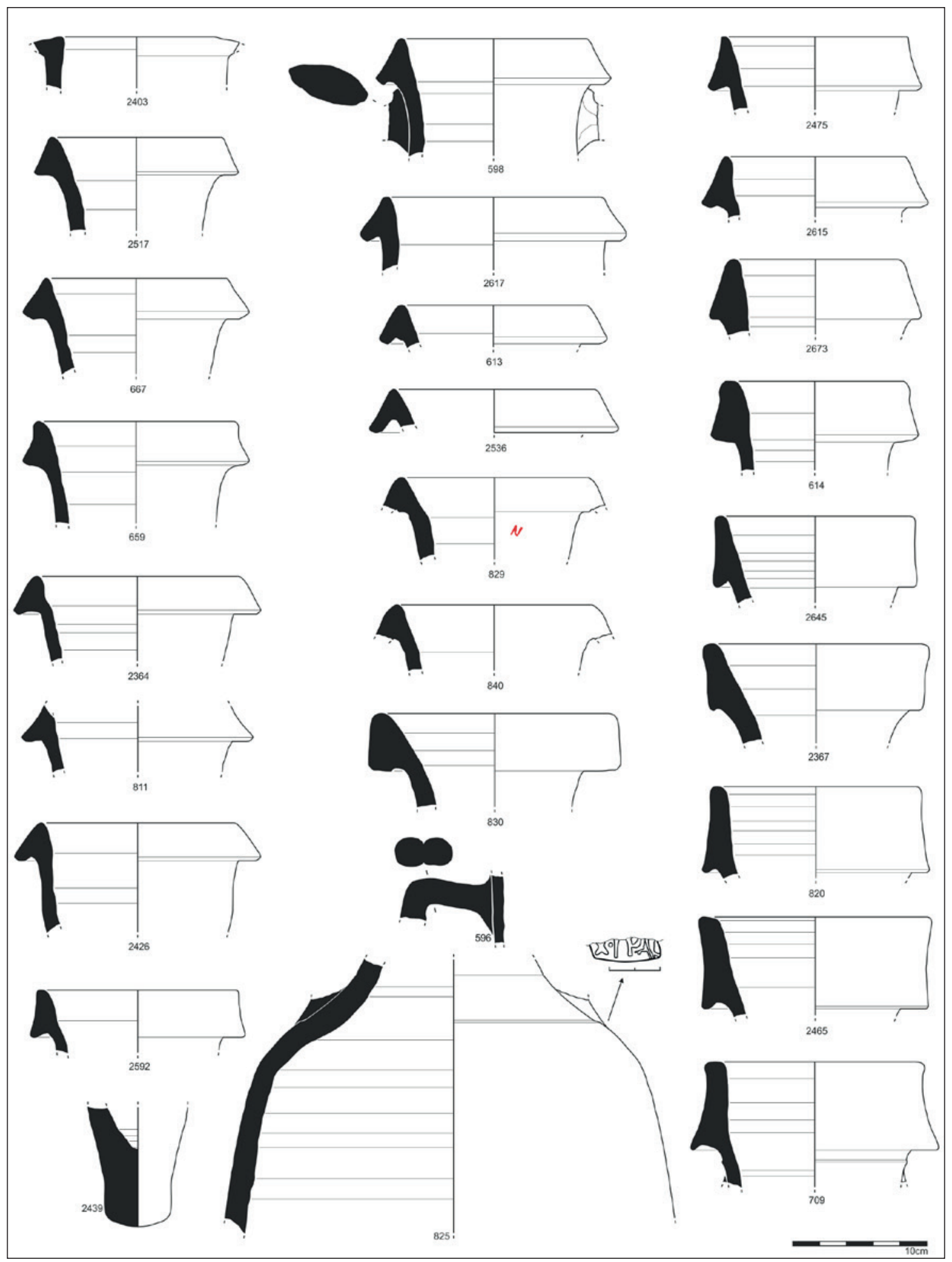

Figura 5. Ânforas vinárias itálicas: Greco-Itálicas (2403, 2517, 667, 659, 2364, 811, 2426, 2592, 598, 2617, 613, 2536, 829 e 840); Dressel 1 (2475, 2615, 2673, 614, 2645, 2367, 820, 2465 e 709); Lamboglia 2 (830); Dressel 2-4 (596); ombro de Greco-Itálica ou Dressel 1 com marca de oleiro (825). Ânforas de fabrico itálico (Ilha de Lipari) destinadas a outros conteúdos: Richborough 527 (2439). 


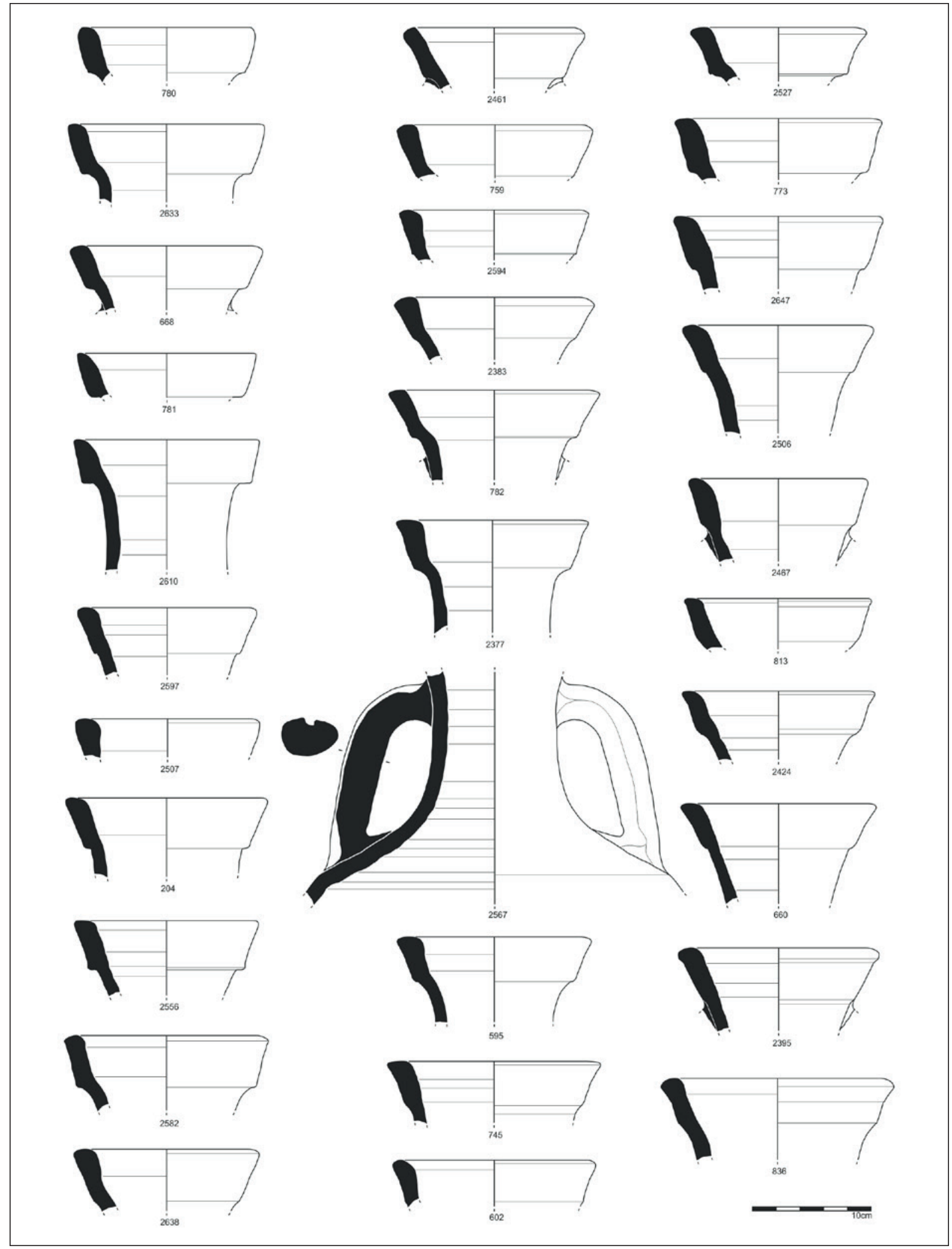

Figura 6. Ânforas vinárias béticas (Guadalquivir): Haltern 70. 


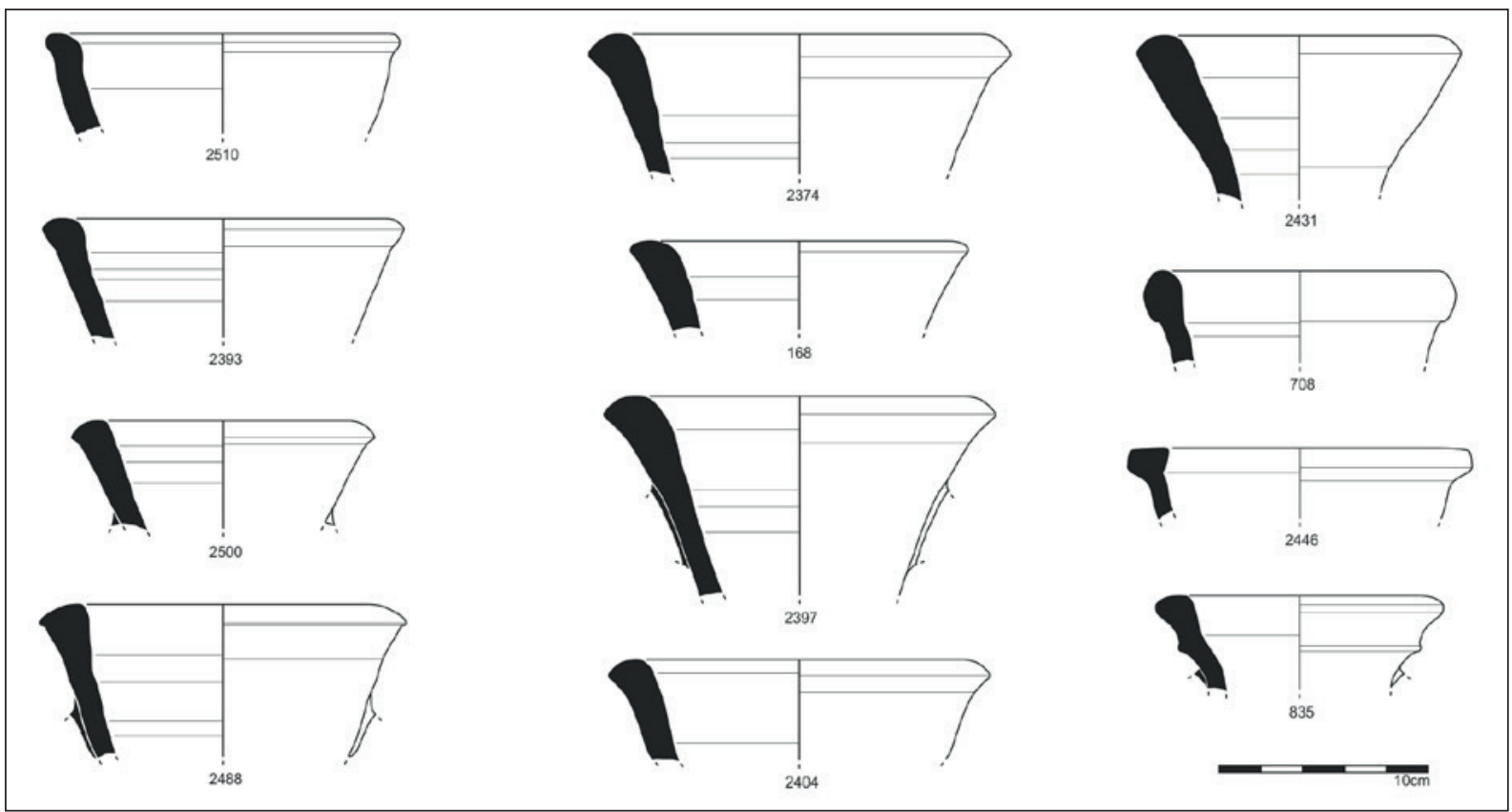

Figura 7. Ânforas vinárias béticas: Verulamium 1908 (2510, 2393, 2500, 2488, 2374, 168, 2397, 2404 e 2431), Guadalquivir; Dressel 2-4 (708), Guadalquivir; ânfora tipo Urceus (2446), Guadalquivir; e Dressel 28 (835), Bética costeira.

a antecedeu, e a Haltern 71, que a sucede, constitui-se como um elemento que contribui particularmente para a dificuldade em distinguir entre uns e outros tipos, principalmente quando nos confrontamos com pequenos fragmentos de bordo, o que acontece com o presente conjunto.

De facto, e tal como sublinhou Almeida (2008: 143), quando nos deparamos com exemplares fragmentados torna-se extremamente difícil distinguir entre os três tipos. Recorde-se, a título de exemplo da dificuldade em classificar os modelos arcaicos comummente designados como ânforas ovoides, o exemplar de perfil completo n. ${ }^{\circ} 1000$ da Lomba do Canho (Fabião 1989: 62, fig. 4), então atribuído à forma Haltern 70, "unusually small variant" de Peacock e Williams (1986), e variante A de Fabião (Idem), e mais tarde reclassificada pelo mesmo autor como Dressel 25 (Fabião 2000: 669).

Naturalmente, esta confusão reporta-se a uma época em que o estado sobre esta questão era ainda muito precoce, envolvendo a discussão acerca dos primeiros modelos anfóricos de tipologia ovoide fabricados na Bética, e que detinham alguns traços morfológicos

Figura 8. Marca de oleiro in radice ansae sobre ânfora de tipo GrecoItálico ou Dressel 1, de difícil leitura.

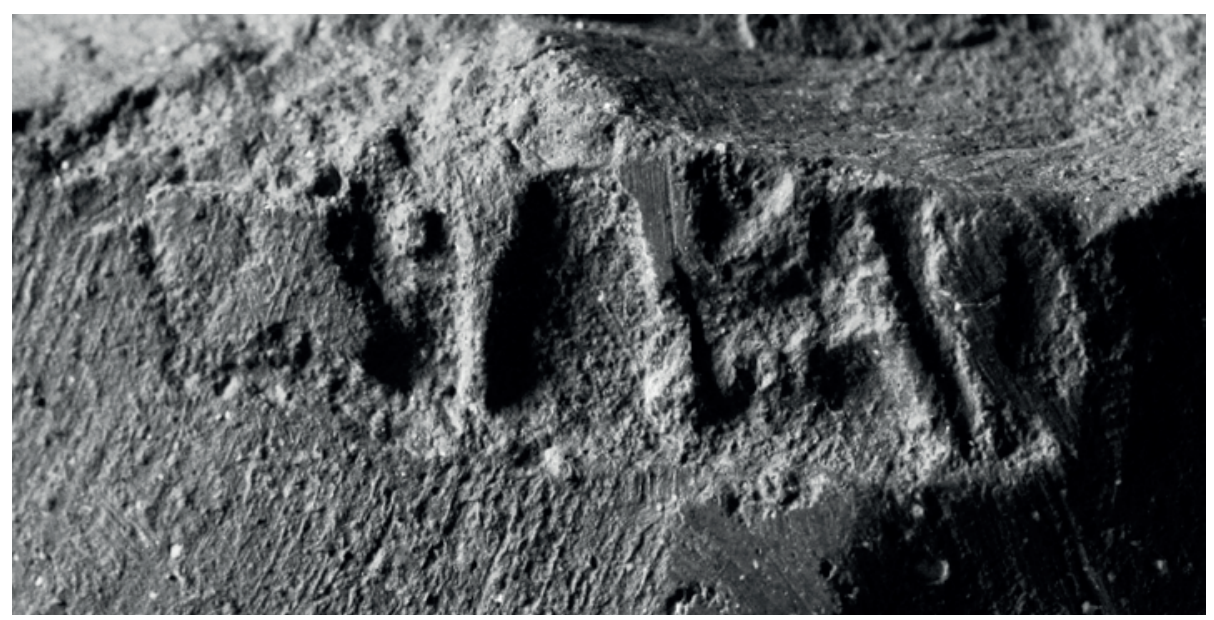




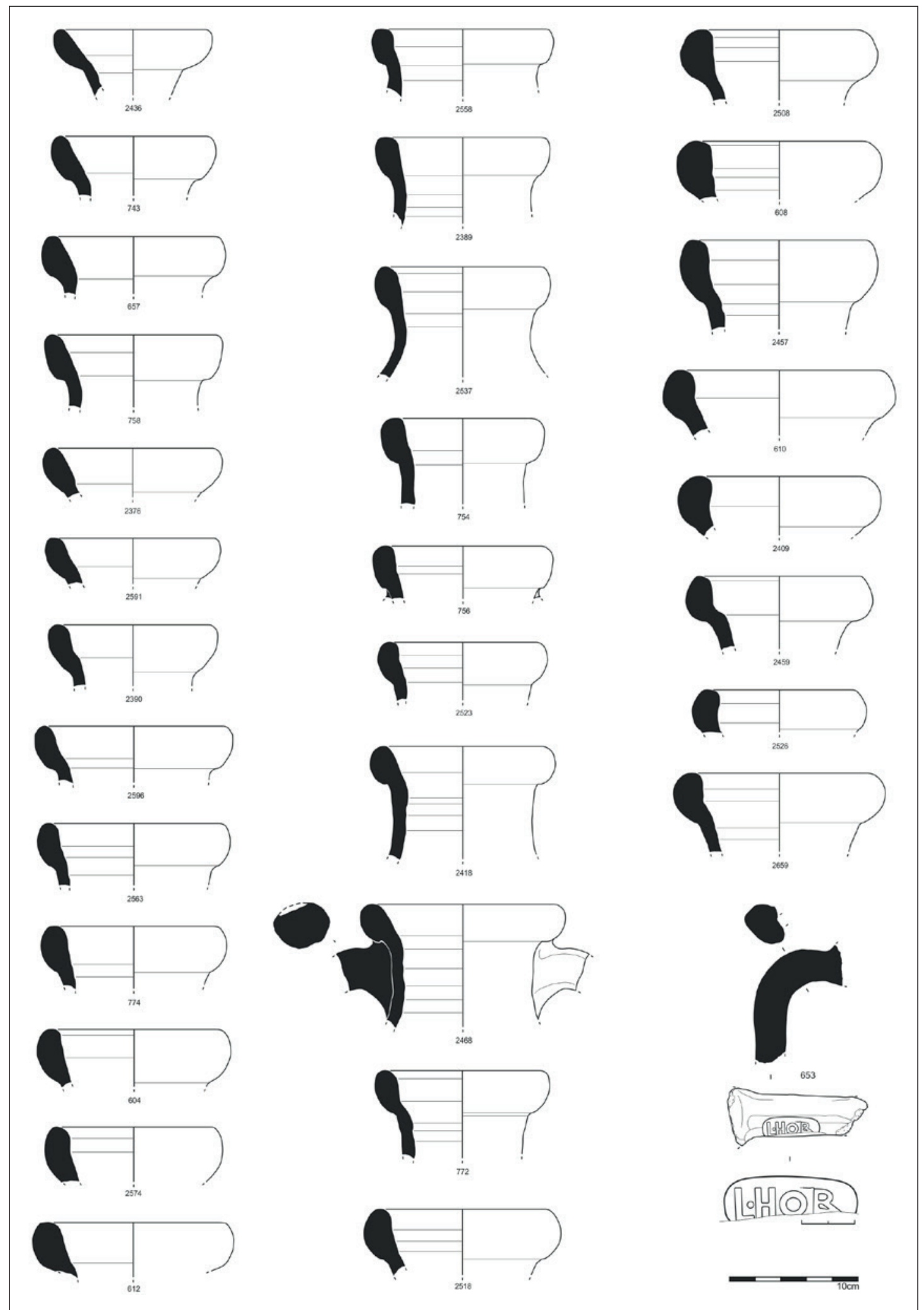

Figura 9. Ânforas oleícolas béticas (Guadalquivir): Oberaden 83. 


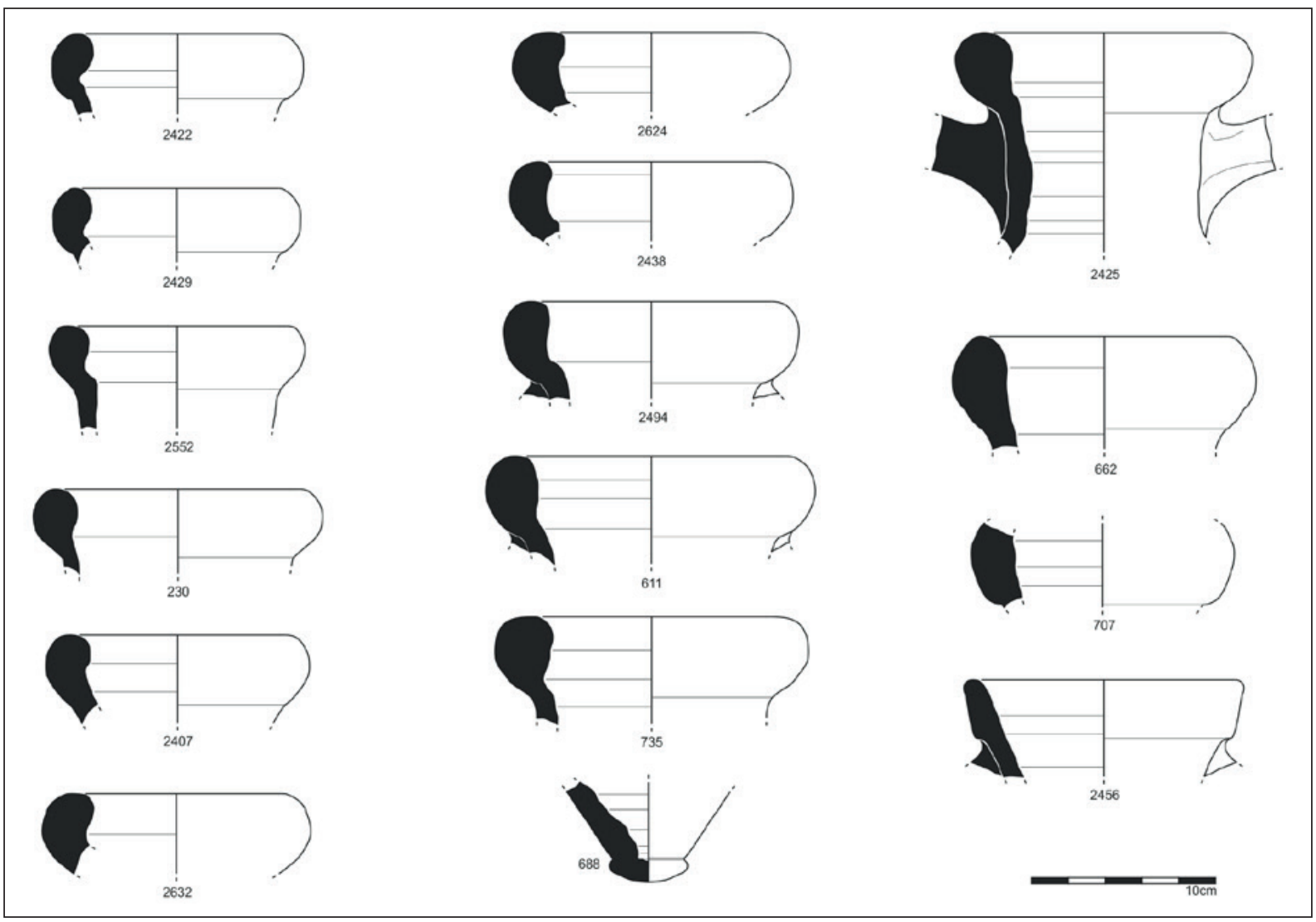

Figura 10. Ânforas oleícolas béticas (Guadalquivir): Dressel 20 (2422, 2429, 2552, 230, 2407, 2632, 2624, 2438, 2494, 611, 735, 2425, 662 e 707). Ânforas oleícolas Norte africanas (Tripolitânia): Tripolitana Antiga (2456 e 688).

comuns a todos - asas com uma depressão longitudinal no dorso e com uma digitação no remate ao ombro, fundos cónicos invariavelmente preenchidos com uma bola de argila, bordo em banda e a generalização do opérculo em argila -, indiciando uma origem análoga no espaço e no tempo, e o mesmo "saber fazer" (idem: 669 e 670). (Figuras 9 e 10)).

Se tivermos em conta a variedade e similitude formal que caracteriza os três tipos, Ovoide 6, Oberaden 83 e Haltern 71, rapidamente nos apercebemos que, quando perante pequenos fragmentos de bordo, a sua classificação se reveste inevitavelmente de contornos falíveis.

A atribuição do tipo Oberaden 83 aos exemplares do teatro romano de Lisboa (pelo menos alguns deles) não está, face ao que se referiu, isenta de possíveis equívocos. A similitude formal, principalmente ao nível dos bordos, entre esta forma e as formas Ovoide 6 e Haltern 71 traduz-se na possibilidade de existirem alguns fragmentos de bordo que, na realidade, pertençam a um dos outros tipos. Da mesma forma, os $n^{\circ}$ s 780 e 781, que neste trabalho se atribuem ao tipo Haltern 70, apresentam características formais ao nível do bordo que os aproximam substancialmente do Subgrupo 1 e 2 do Grupo IX de Santarém (Almeida 2008), podendo, eventualmente, tratar-se de exemplares dessa tipologia. Sublinhe-se que o referido tipo foi produzido na bacia do Guadalquivir a partir do segundo quartel do século I a.C., estando documentado em locais como Santarém (Almeida 2008), Mesas do Castelinho, Lomba do Canho (Fabião 1989, 1998b e 2000) e Conímbriga (Buraca 2005).

Identificou-se ainda a marca de oleiro L. HOR ( $L$. Horati - n. ${ }^{\circ}$ 653). Foi aplicada sobre uma asa curta, de secção subcircular e com uma depressão longitudinal no dorso, de uma ânfora produzida com as típicas pastas do Guadalquivir. Embora se tenha optado por agrupar este fragmento na tipologia Oberaden 83 - pelas características morfológicas mas também pelo facto de aquela marca ser conhecida sobretudo em ânforas de tipo Oberaden 83 , tipologia que se encontra bem representada no teatro -, as suas características morfológicas poderiam igualmente autorizar a sua classificação dentro dos tipos Ovoide 6, Haltern 70 ou Classe 67. (Figura 11). 


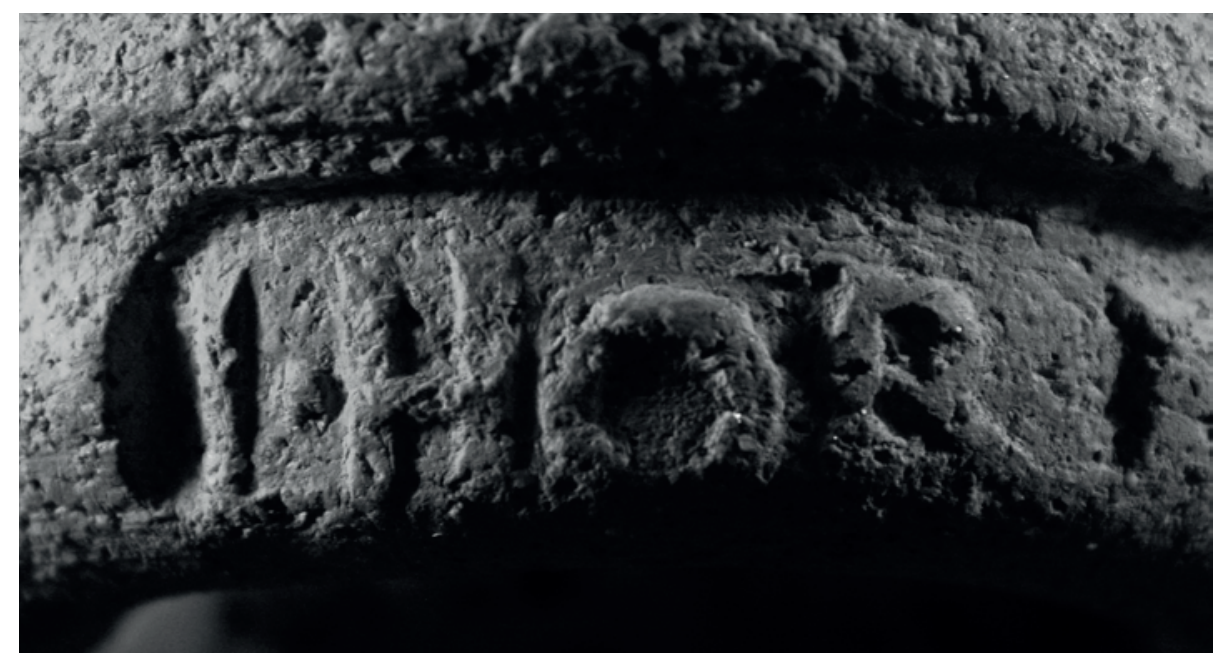

Figura 11. Marca sobre asa de ânfora Oberaden 83 (Guadalquivir): $L$. Horati.
Trata-se de uma marca bem documentada na fachada atlântica, estando registada no Castro de Vigo (Hidalgo Cuñarro 1987; CEIPAC 4863), Castro de Santa Tecla (Beltran Lloris 1970; CEIPAC 27236), Castro de Vieito, Ponte de Lima (Silva 2008), Santarém (Almeida 2008), La Alcudia, Elche (Márquez Villora e Molina Vidal 2001; CEIPAC 24073), Baetulo, Badalona (Comas i Solá 1997; CEIPAC 18061) e Mahón, Menorca (De Nicolas 1979; CEIPAC 12612).

Parece clara a relação entre a marca do teatro e aquelas identificadas em Santarém e em outros locais da Península Ibérica, nomeadamente os exemplares do Noroeste da península, indiciando uma rede de abastecimento comum, muito provavelmente enquadrável na rota atlântica.

O exemplar do teatro romano provém de um depósito medieval. Contudo, as marcas relacionáveis documentadas em Santarém foram exumadas em níveis atribuíveis a Augusto/inícios de Tibério (Almeida 2008) e a peça de Baetulo em contextos datáveis entre 27 e 1 a.C. (Comas i Solá 1997), pelo que a marca do teatro romano dever-se-á, muito provavelmente, enquadrar no mesmo âmbito cronológico.

\section{4. Ânforas piscícolas}

As ânforas destinadas ao transporte de produtos piscícolas são sobretudo provenientes da região meridional peninsular e da Lusitânia, com a excepção de um único fragmento de bordo de Mañá C2 (T-7.4.3.1.), fabricada na área de Cartago-Tunes, constituindo-se como uma imitação/evolução dos modelos da região da Tripolitana produzidos a partir do último quartel do século III a.C. (Ramón Torres 1995: 206). Da região meridional peninsular estão presentes as ânforas piscícolas T-9.1.1.1., Mañá C2 (T-7.4.3.3.), Greco-Itálicas hispânicas, Classe 67, Dressel 12 e Dressel 7-11, abarcando um arco cronológico que se estende desde a presença romana mais antiga no extremo ocidente peninsular, terceiro quartel do séc. II a.C., até ao terceiro quartel do séc. I d.C.

A forma melhor representada é a Mañá C2 (T7.4.3.3.), tendo sido recolhidos 30 fragmentos de bordo produzidos nas oficinas do "Círculo do Estreito de Gibraltar, em contextos romanos da Fase 1 e da Fase 2, bem como em níveis medievais e modernos. As Mañá C2 (T-7.4.3.3.) equivalem a 14,22\% do NMI, sendo uma das tipologias melhor representadas. Quanto às Dressel 7-11, foram identificados 16 fragmentos de bordo, correspondendo a $8 \%$ do NMI. Com excepção do fragmento n. ${ }^{\circ} 2380$, que apresenta as típicas pastas do Guadalquivir, todos os exemplares são provenientes da região costeira da Bética. A maioria destas ânforas foi exumada em contextos romanos da Fase 2, e as restantes em níveis medievais e modernos. As T-9.1.1.1., Greco-Itálicas hispânicas, Classe 67 e Dressel 12 têm pouca representação no conjunto, tendo-se documentado três fragmentos de bordo do primeiro tipo e um bordo de cada uma das outras formas.

As ânforas de produção lusitana do conjunto do teatro romano integram-se, crono e tipologicamente, no conjunto das mais precoces produções anfóricas plenamente romanas fabricadas na Lusitânia, tendo vindo nos últimos anos a ser genericamente designadas de "Ovoides Lusitanas" (Morais 2003; Pimenta et al. 2006; Morais e Fabião 2007; Filipe 2008; Fabião 2008). 
Foram identificados quarenta fragmentos de bordo que encontram bons paralelos formais em alguns exemplares de Alcácer do Sal (Pimenta et al. 2006: 306, fig. 5), de Santarém (Arruda et al. 2006: 240 e 242, figs. 3 e 4), de Lisboa (Morais e Fabião 2007: fig. 1, concretamente o n. ${ }^{\circ}$ 1; Fernandes et al. 2006; Filipe 2008), de Abul (Mayet e Silva 2002: 130 a 136, figs. 52 a 58), de Setúbal (Silva 1996: 54, fig. 4) e do Pinheiro (Mayet e Silva 1998: 89 e 90, figs. 19 e 20), ou mesmo em algumas peças do Castro de Santa Tecla (Morais e Fabião 2007: 132).

Cerca de metade deste conjunto é proveniente de níveis medievais e modernos, tendo-se registado treze exemplares em contextos romanos da Fase 2, terceiro quartel do século I, e sete fragmentos de bordo em contextos da Fase 1, enquadrável no principado de Augusto.

É inegável a importância do reconhecimento destes conjuntos anfóricos nos centros de consumo, cujas características formais nos reportam aos materiais tardo-republicanos apresentados por Rui Morais e Carlos Fabião (Morais 2003; Morais e Fabião 2007), contribuindo, entre outros factores, para uma melhor percepção do que terá sido a geografia de distribuição destes contentores, a sua expressão quantitativa e variedade formal. (Figuras 12-15)

Contudo, um denominador comum parece acompanhar quase todos os casos expostos (diria mesmo todos com excepção daqueles recolhidos em níveis augustanos em Santarém e em níveis republicanos na rua dos Correeiros em Lisboa): a inexistência de materiais recolhidos em contexto primário e associados a estratigrafias seguras que permitam comprovar a antiguidade dessas produções e precisar a cronologia da sua produção e difusão. O estado fragmentado da esmagadora maioria desses materiais tem impedido, de igual modo, uma melhor tipificação destas ânforas.

Trata-se de produções que terão tido início por volta de 30 a.C., podendo eventualmente recuar até meados desse século, e ter-se-ão estendido até ao primeiro terço/ meados do século I d.C. (Morais e Fabião 2007: 131).

\section{5. Ânforas destinadas a outros conteúdos}

Para além das ânforas destinadas a transportar vinho, azeite e produtos piscícolas, foram ainda identificados dois fragmentos (um fundo e uma asa) do tipo Richborough 527, ânfora destinada a transportar "Alun", produzida na Ilha de Lipari no Sul de Itália, entre o segundo quartel do século I a.C. e o século III/ inícios do século IV d.C. (Borgard 1994: 197; 2005: 157 e 158).

\section{APRECIAÇÃO QUANTITATIVA}

No quadro geral dos materiais cerâmicos exumados no decurso das recentes intervenções no teatro romano de Lisboa, as ânforas correspondem, com excepção, talvez, da cerâmica comum, à categoria quantitativamente mais expressiva. De entre a totalidade de peças existentes, foram identificados e seleccionados 532 fragmentos, a que correspondem 209 bordos, 247 asas e 76 fundos, atribuíveis a 19 tipologias distintas, traduzindo-se num Número Mínimo de 211 Indivíduos (NMI), acrescentando-se ainda um conjunto de 44 opérculos.

A apreciação quantitativa do presente conjunto afigura-se pertinente numa perspectiva de análise global, uma vez que uma percentagem significativa destas ânforas foi documentada em contextos de época Medieval, Moderna e Contemporânea. Por outro lado, e no que se refere aos materiais exumados em contextos de época romana, quantitativamente o conjunto em apreço adquire especial significado se se tiver em conta que provém de contextos genericamente balizados entre o período de Augusto e o terceiro quartel do século I d.C., ou seja, reporta-se a um período relativamente curto e bem circunscrito no tempo, permitindo uma leitura privilegiada sobre os ritmos de consumo e dinâmica comercial de Olisipo durante este período. Acrescente-se ainda que, de acordo com os pressupostos de Molina Vidal (1997: 47), a amostra do teatro romano pode considerar-se de "fiabilidade aceitável", uma vez que a quantidade de bordos é superior a 200.

No conjunto global das ânforas do teatro romano (NMI) destaca-se o predomínio das produções meridionais hispânicas, que correspondem a $67 \%$, particularmente os fabricos atribuíveis à região do Guadalquivir que representam $65 \%$ dentro das produções do Sul peninsular. A Lusitânia constitui-se como a segunda região produtora melhor representada, 19\%, enquanto a Península Itálica, sobretudo representada pelos vinhos tirrénicos e adriáticos, corresponde a $13 \%$. As produções africanas correspondem apenas a 1\%, e materializam-se em um exemplar de Mañá C2 (T-7.4.3.1.), contentor piscícola proveniente da região de Cartago/Tunes, e um outro de tipo Tripolitana Antiga, ânfora oleícola procedente da região da Tripolitânia, na actual Líbia.

Os preparados piscícolas parecem ter sido os produtos preferentemente importados, representando $44 \%$ do total de NMI, quer numa fase mais recuada, em ânforas Mañá C2, T-9.1.1.1. e Greco-Itálicas Hispânicas, quer a partir do terceiro/último quartel do século I a.C., em contentores de tipo Classe 67, Dressel 7-11, Dressel 12 e Ovoides Lusitanas. No que diz respeito à fase mais 


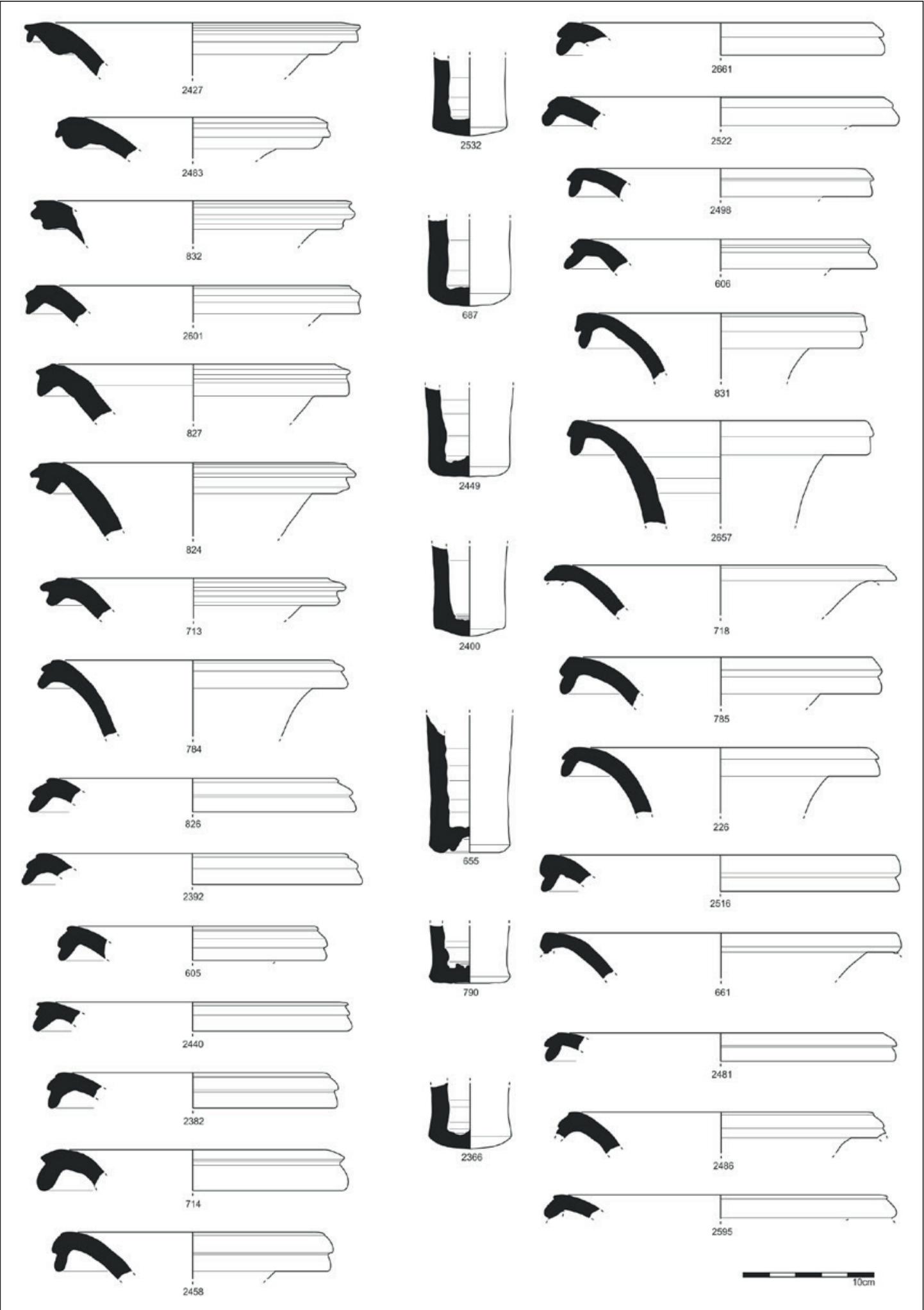

Figura 12. Ânforas piscícolas da baía gaditana: Mañá C2 (T-7.4.3.3.). Ânfora piscícola Norte africana: Mañá C2 (T-7.4.3.1.) (2595). 


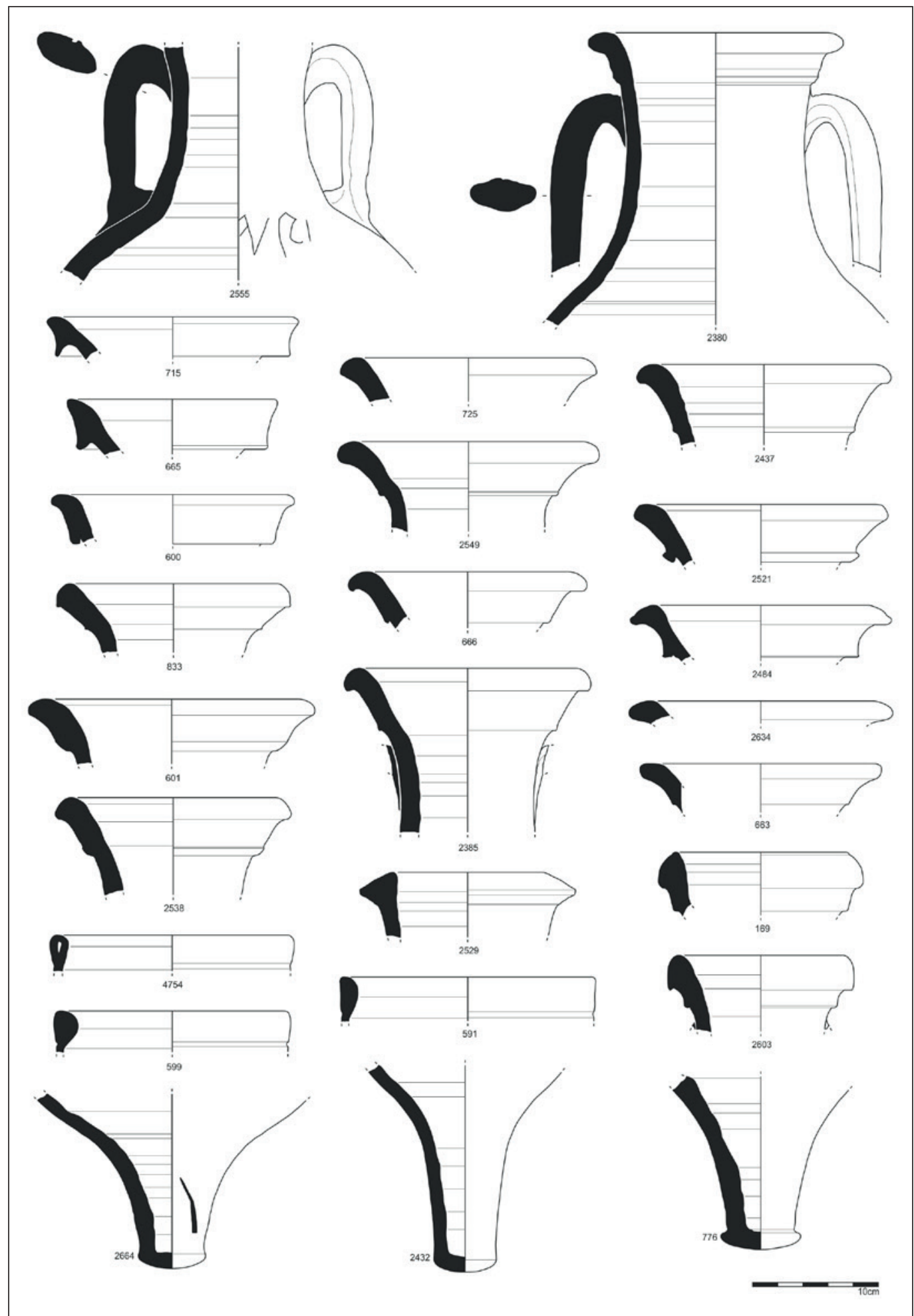

Figura 13. Ânforas piscícolas da região meridional hispânica: Dressel 7-11 (região costeira: 2555, 715, 665, 600, 833, 601, 2538, 725, 2549, 666, 2385, 2437, 2521, 2484, 2634, 663, 2664, 2432 e 776; Guadalquivir: 2380); T-9.1.1.1. (4754, 599 e 591), baía gaditana; Greco-Itálica (2529), baía gaditana; Classe 67 (169), Guadalquivir; e Dressel 12 (2603), Guadalquivir. 


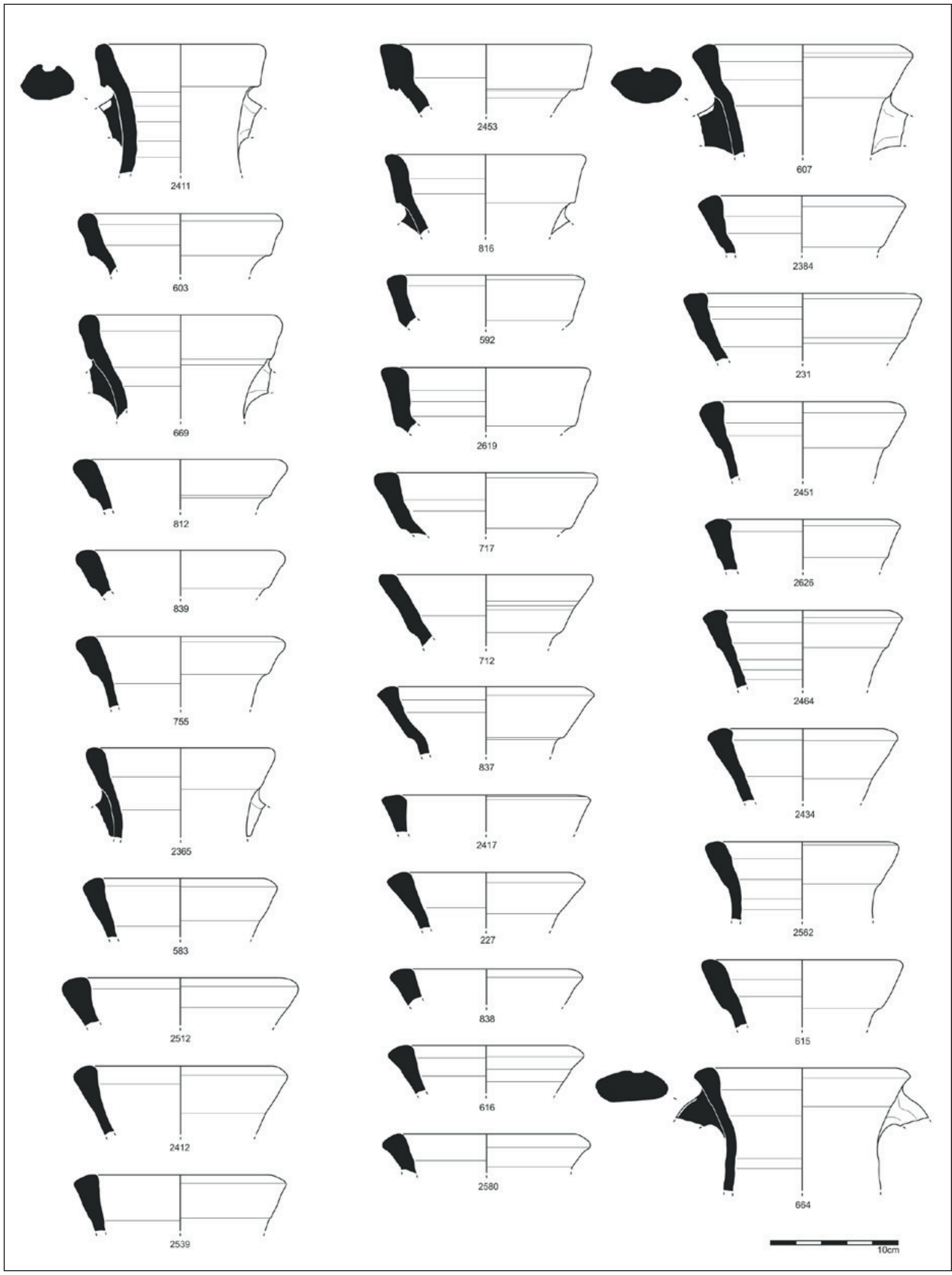

Figura 14. Ânforas piscícolas de produção lusitana: Lusitanas antigas. 


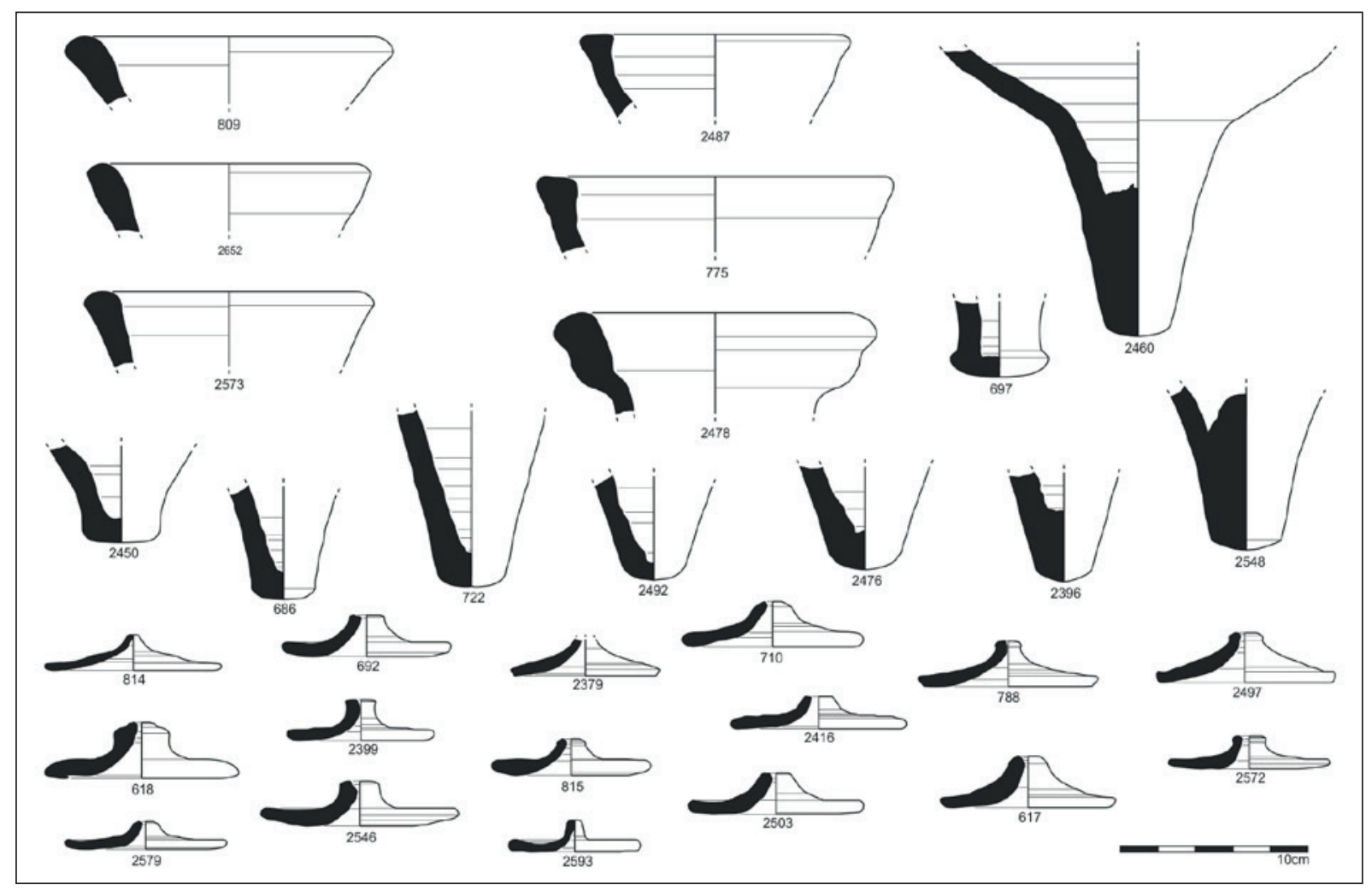

Figura 15. Ânforas piscícolas de produção lusitana: Lusitanas antigas.

recuada, não deixa de ser curioso que no teatro romano as ânforas piscícolas hispânicas se registem em maior número $(55 \%)$ que as vinárias itálicas $(42 \%)$ - e dentro destas últimas uma maior quantidade de Greco-Itálicas -, algo que não sucede, por exemplo, no castelo de São Jorge (Pimenta 2005) e em Santarém (Arruda e Almeida 1999; Bargão 2006), onde se assiste a uma clara preponderância das últimas, especialmente do tipo Dressel 1. ((Figuras 16 e 17).

Sobrepondo estes dados com os relativos às ocupações republicanas do castelo de São Jorge verifica-se, principalmente a partir da segunda metade do século I a.C. e inícios do século seguinte, um acentuado decréscimo das importações itálicas em Olisipo em detrimento dos produtos provenientes da bética. $\mathrm{O}$ vinho itálico é gradualmente substituído pelo vinho meridional hispânico, embora a presença de tipologias como a Dressel 2-4 possa indicar a continuidade da importação de vinhos itálicos, ainda que em percentagens quase residuais. O vinho representa $34 \%$ no total de NMI.

Relativamente ao vinho bético ( $62 \%$ das ânforas vinárias), está principalmente documentado pela presença significativa de ânforas produzidas na região interior do

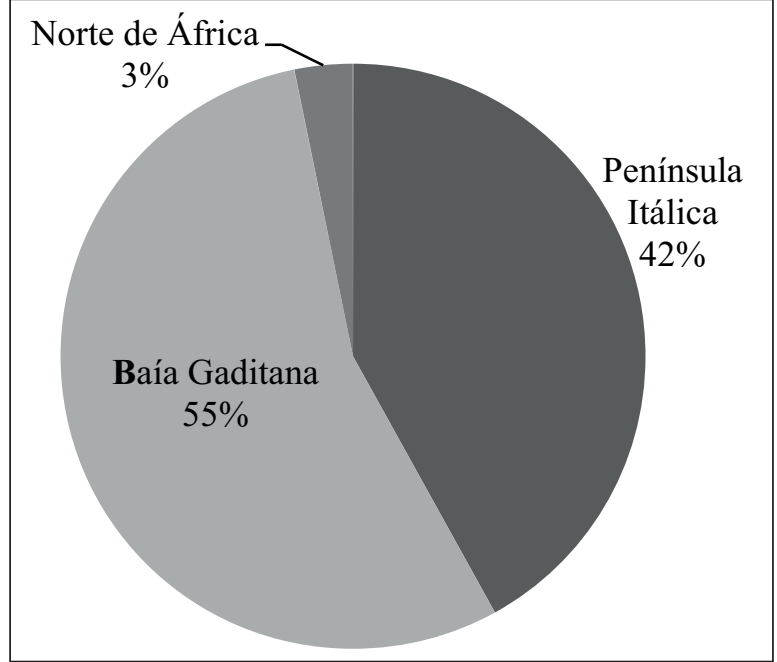

Figura 16. Representação das áreas produtoras em Época republicana (NMI).

vale do Guadalquivir que se destinariam ao transporte do apreciado líquido, como as Haltern 70 (45\%), Verulamium 1908 (13\%), Dressel 2-4 (1\%) e ânforas de tipo 


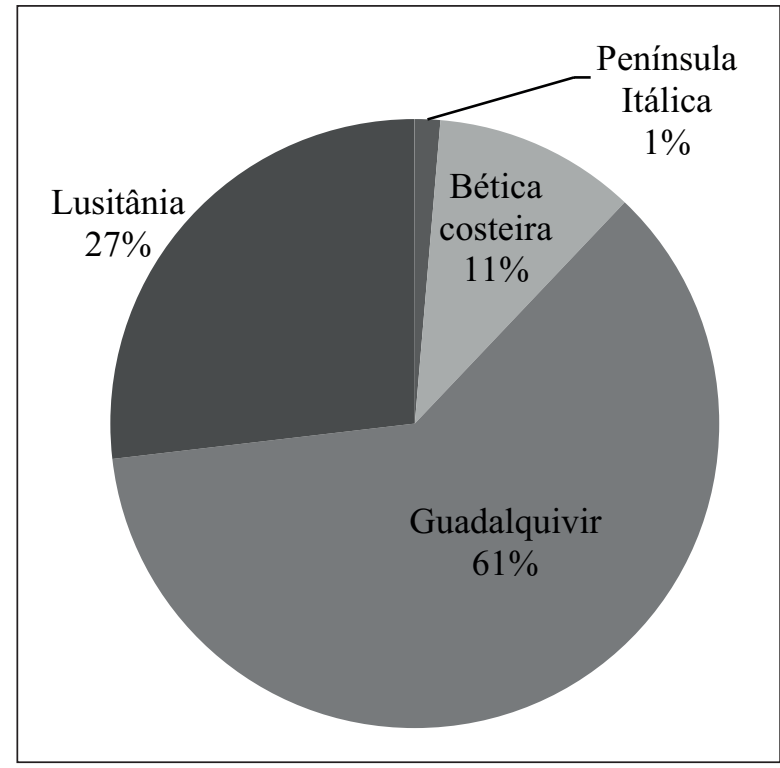

Figura 17. Representação das áreas produtoras em Época Alto Imperial (NMI).

Urceus (1\%), bem como por ânforas produzidas nas regiões costeiras daquela província, como a Dressel 28 (1\%). (Figuras 18 e 19). (Tabela 1).

O desabrochar da indústria piscícola na Lusitânia a partir, pelo menos, do último quartel do século I a.C., representado no teatro por um conjunto bastante expressivo das mais precoces produções anfóricas daquela província, vem aduzir algumas mudanças nos ritmos de importação e nas dinâmicas comerciais

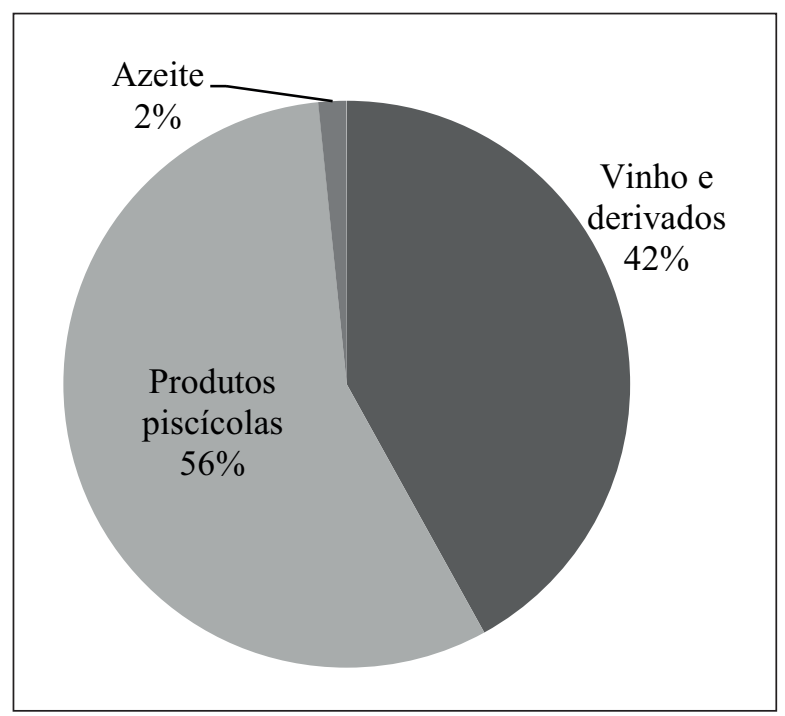

Figura 18. Produtos importados e consumidos em Época republicana (NMI). de então. De facto, pelo que os dados do teatro indicam, o consumo de preparados piscícolas béticos em Olisipo parece diminuir, relativamente ao período anterior, verificando-se, a partir do principado de Augusto, a predominância dos produtos de origem lusitana, representando $65 \%$.

No que se refere ao azeite, foram identificadas 46 ânforas destinadas ao seu transporte $(22 \%$ do total de NMI), constatando-se que foi importado quase exclusivamente da província da Bética $(98 \%$ das ânforas oleícolas), concretamente da região do vale do Guadalquivir, com excepção de uma ânfora da forma Tripolitana Antiga (2\%), proveniente da região da Tripolitânia no Norte de África. Num período mais recuado observa-se a importação do azeite africano em fracas quantidades. A partir do principado de Augusto o azeite bético começa a chegar em grandes quantidades transportado primeiro em ânforas de tipo Oberaden 83, e depois, já em meados/terceiro quartel do século I d.C., nas suas sucessoras Dressel 20. (Tabela 2).

\section{CONSIDERAÇÕES FINAIS}

Os dados que foram expostos ao longo deste trabalho permitem tecer algumas considerações acerca do significado da amostra disponível, autorizando uma análise dos aspectos relacionados com a origem dos contentores identificados e dos produtos transportados, e possibilitando, ainda que partindo de um conjunto obviamente truncado - aliás, condição intrínseca a todos

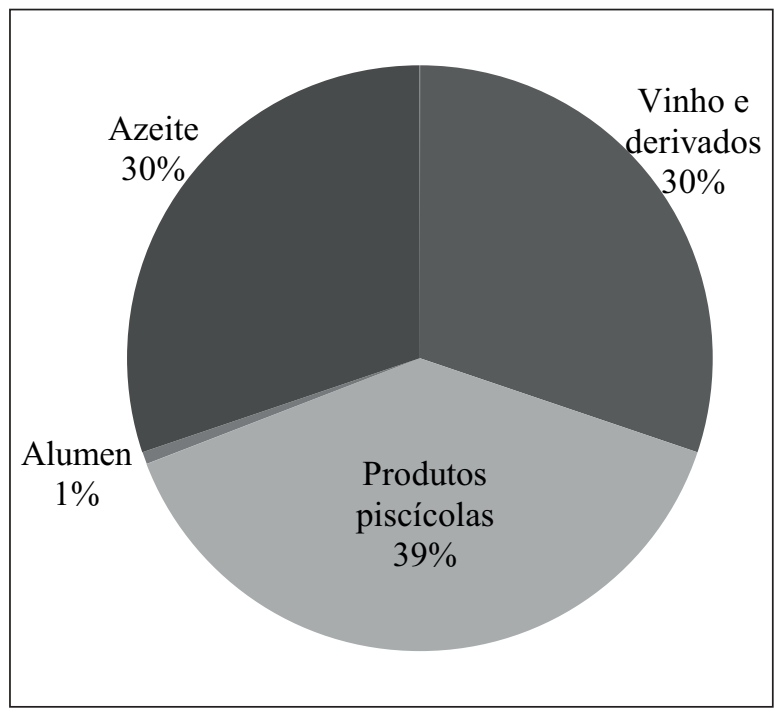

Figura 19. Produtos consumidos em Época Alto Imperial.

ISSN: 1133-4525 ISSN-e: 2255-3924 http://dx.doi.org/10.12795/spal.2015i24.06 
Tabela 1. Tabela geral da quantificação por NMI das ânforas do teatro romano (não estão incluídos 31 fragmentos de tipologia indeterminada e 44 opérculos).

\begin{tabular}{|c|c|c|c|c|c|c|c|}
\hline & Conteúdo & Tipologias & $\begin{array}{c}\mathrm{N}^{\mathrm{o}} \\
\text { Fragmentos }\end{array}$ & NMI & $\begin{array}{c}\text { NMI \% } \\
\text { República }\end{array}$ & $\begin{array}{c}\text { NMI \% } \\
\text { Total }\end{array}$ & Proveniência \\
\hline \multirow{8}{*}{$\begin{array}{l}\frac{\pi}{0} \\
\frac{0}{0} \\
\frac{0}{2} \\
\simeq\end{array}$} & \multirow{3}{*}{ Vinho } & Greco-Itálica & \multirow{2}{*}{94} & 14 & $22,58 \%$ & $6,64 \%$ & \multirow{3}{*}{ Península Itálica } \\
\hline & & Dressel 1 Itálica & & 11 & $17,74 \%$ & $5,21 \%$ & \\
\hline & & Lamboglia 2 & 1 & 1 & $1,61 \%$ & $0,47 \%$ & \\
\hline & \multirow{4}{*}{ Peixe } & T-9.1.1.1. / CCNN & 3 & 3 & $4,83 \%$ & $1,42 \%$ & \multirow{3}{*}{ Baía Gaditana } \\
\hline & & Mañá C2 / T-7.4.3.3. & 54 & 30 & $48,39 \%$ & $14,22 \%$ & \\
\hline & & Greco-Itálica Hispânica & 7 & 1 & $1,61 \%$ & $0,47 \%$ & \\
\hline & & Mañá C2 / T-7.4.3.1. & 1 & 1 & $1,61 \%$ & $0,47 \%$ & Cartago-Tunes \\
\hline & \multirow[t]{2}{*}{ Azeite } & Tripolitana Antiga & 2 & 1 & $1,61 \%$ & $0,47 \%$ & Tripolitânia \\
\hline & & Total República & 162 & 62 & $100 \%$, & & \\
\hline
\end{tabular}

\begin{tabular}{|c|c|c|c|c|c|c|c|}
\hline & Conteúdo & Tipologias & $\begin{array}{c}\mathrm{N}^{\mathrm{o}} \\
\text { Fragmentos }\end{array}$ & NMI & $\begin{array}{c}\text { NMI \% } \\
\text { Alto Império }\end{array}$ & $\begin{array}{l}\text { NMI \% } \\
\text { Total }\end{array}$ & Proveniência \\
\hline \multirow{14}{*}{ 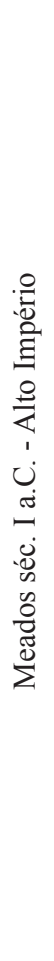 } & \multirow{6}{*}{ Vinho } & Dressel 2-4 Itálica & $3 ?$ & 1 & $0,67 \%$ & $0,47 \%$ & Península Itálica \\
\hline & & Dressel 2-4 Guadalquivir & $3 ?$ & 1 & $0,67 \%$ & $0,47 \%$ & \multirow{4}{*}{ Guadalquivir } \\
\hline & & Haltern 70 & $93 ?$ & 32 & $21,48 \%$ & $15,17 \%$ & \\
\hline & & Tipo Urceus & 1 & 1 & $0,67 \%$ & $0,47 \%$ & \\
\hline & & Verulamium 1908 & 9 & 9 & $6,04 \%$ & $4,27 \%$ & \\
\hline & & Dressel 28 & 1 & 1 & $0,67 \%$ & $0,47 \%$ & Bética Costeira \\
\hline & \multirow{5}{*}{ Peixe } & Classe 67 & $1 ?$ & 1 & $0,67 \%$ & $0,47 \%$ & \multirow{3}{*}{ Guadalquivir } \\
\hline & & Ovoide 1 & 1 & 1 & $0,67 \%$ & $0,47 \%$ & \\
\hline & & Dressel 7-11 Guadalquivir & 2 & 1 & $0,67 \%$ & $0,47 \%$ & \\
\hline & & Dressel 7-11 Bética costeira & $20 ?$ & 15 & $10,07 \%$ & $7,11 \%$ & Bética Costeira \\
\hline & & Lusitanas antigas & 104 & 40 & $26,85 \%$ & $18,96 \%$ & Lusitânia \\
\hline & \multirow{2}{*}{ Azeite } & Oberaden 83 & \multirow{2}{*}{99} & 31 & $20,81 \%$ & $14,69 \%$ & \multirow{2}{*}{ Guadalquivir } \\
\hline & & Dressel 20 & & 14 & $9,39 \%$ & $6,64 \%$ & \\
\hline & $\begin{array}{l}\text { Outros } \\
\text { produtos }\end{array}$ & Richborough 527 & 2 & 1 & $0,67 \%$ & $0,47 \%$ & Ilha de Lipari \\
\hline & & Total Alto Império & 339 & 149 & $100 \%$ & & \\
\hline & & Total da amostra & $501 *$ & 211 & & $100 \%$ & \\
\hline
\end{tabular}


Tabela 2. Catálogo com a procedência estratigráfica das ânforas exumadas em contextos romanos e respectiva fase (não estão incluídas as peças identificadas em contextos medievais e modernos).

\begin{tabular}{|c|c|c|c|c|c|c|c|c|}
\hline $\mathrm{N}^{\mathrm{o}}$ Inv. & Ano & Vala & Camada & Fase & Fragmento & Tipologia & Produção & Diâmetro bordo \\
\hline 592 & 2006 & 10 & 13 & Fase 1 & Bordo & "Ovoides Lusitanas" & Lusitânia & 15,4 \\
\hline 755 & 2006 & 11 & $11 \mathrm{a}$ & Fase 1 & Bordo & "Ovoides Lusitanas" & Lusitânia & 16,4 \\
\hline 809 & 2006 & 11 & $18 \mathrm{~b}$ & Fase 1 & Bordo & "Ovoides Lusitanas" & Lusitânia & 17,5 \\
\hline 810 & 2006 & 11 & $18 \mathrm{~b}$ & Fase 1 & Bordo & "Ovoides Lusitanas" & Lusitânia & $?$ \\
\hline 812 & 2006 & 11 & $18 \mathrm{~b}$ & Fase 1 & Bordo & "Ovoides Lusitanas" & Lusitânia & 16,8 \\
\hline 816 & 2006 & 11 & 20 & Fase 1 & Bordo & "Ovoides Lusitanas" & Lusitânia & 15,7 \\
\hline 591 & 2006 & 10 & 13 & Fase 1 & Bordo & T-9.1.1.1. - CCNN & Baía gaditana & 20,4 \\
\hline 798 & 2006 & 11 & 18 & Fase 1 & Bordo & Dressel 1 & Itálica & $>15$ \\
\hline 820 & 2006 & 11 & 22 & Fase 1 & Bordo & Dressel 1 & Itálica & 17,2 \\
\hline 828 & 2006 & 11 & 16 & Fase 1 & Bordo & Dressel 1 & Itálica & $>14,8$ \\
\hline 2673 & 2005 & 10 & 11 & Fase 1 & Bordo & Dressel 1 & Itálica & 15,9 \\
\hline 825 & 2006 & 11 & 24 & Fase 1 & Arranque asa & Dressel 1 / Greco-Itálica & Itálica & l \\
\hline 811 & 2006 & 11 & $18 \mathrm{~b}$ & Fase 1 & Bordo & Greco-itálica & Itálica & 17,5 \\
\hline 829 & 2006 & 11 & 16 & Fase 1 & Bordo & Greco-itálica & Itálica & $>16,3$ \\
\hline 759 & 2006 & 11 & $12 \mathrm{a}$ & Fase 1 & Bordo & Haltern 70 & Guadalquivir & 16,6 \\
\hline 813 & 2006 & 11 & $18 \mathrm{~b}$ & Fase 1 & Bordo & Haltern 70 & Guadalquivir & 15,8 \\
\hline 830 & 2006 & 11 & 16 & Fase 1 & Bordo & Lamboglia 2 & Itálica & 17,8 \\
\hline 589 & 2006 & 10 & 13 & Fase 1 & Bordo & Mañá C2 - T-7.4.3.3. & Baía gaditana & $?$ \\
\hline 824 & 2006 & 11 & 24 & Fase 1 & Bordo & Mañá C2 - T-7.4.3.3. & Baía gaditana & 24,8 \\
\hline 826 & 2006 & 11 & 16 & Fase 1 & Bordo & Mañá C2 - T-7.4.3.3. & Baía gaditana & 25 \\
\hline 827 & 2006 & 11 & 16 & Fase 1 & Bordo & Mañá C2 - T-7.4.3.3. & Baía gaditana & 24 \\
\hline 831 & 2006 & 11 & 16 & Fase 1 & Bordo & Mañá C2 - T-7.4.3.3. & Baía gaditana & 22,4 \\
\hline 832 & 2006 & 11 & 16 & Fase 1 & Bordo & Mañá C2 - T-7.4.3.3. & Baía gaditana & 24,8 \\
\hline 754 & 2006 & 11 & $11 \mathrm{a}$ & Fase 1 & Bordo & Oberaden 83 & Guadalquivir & 13 \\
\hline 756 & 2006 & 11 & $11 \mathrm{a}$ & Fase 1 & Bordo & Oberaden 83 & Guadalquivir & 14 \\
\hline 758 & 2006 & 11 & $12 \mathrm{a}$ & Fase 1 & Bordo & Oberaden 83 & Guadalquivir & 14 \\
\hline 583 & 2006 & 10 & 7 & Fase 2 & Bordo & "Ovoides Lusitanas" & Lusitânia & 15,2 \\
\hline 712 & 2006 & 11 & $6 \mathrm{a}$ & Fase 2 & Bordo & "Ovoides Lusitanas" & Lusitânia & 16,8 \\
\hline 717 & 2006 & 11 & 7 & Fase 2 & Bordo & "Ovoides Lusitanas" & Lusitânia & 17,2 \\
\hline 775 & 2006 & 11 & 14 & Fase 2 & Bordo & "Ovoides Lusitanas" & Lusitânia & 19 \\
\hline 837 & 2006 & 11 & 6 & Fase 2 & Bordo & "Ovoides Lusitanas" & Lusitânia & 17 \\
\hline 839 & 2006 & 11 & 13 & Fase 2 & Bordo & "Ovoides Lusitanas" & Lusitânia & 16,4 \\
\hline 2512 & 2005 & 9 & 6 & Fase 2 & Bordo & "Ovoides Lusitanas" & Lusitânia & 18,4 \\
\hline
\end{tabular}




\begin{tabular}{|c|c|c|c|c|c|c|c|c|}
\hline $\mathrm{N}^{\mathrm{o}}$ Inv. & Ano & Vala & Camada & Fase & Fragmento & Tipologia & Produção & Diâmetro bordo \\
\hline 2539 & 2005 & 9 & 11 & Fase 2 & Bordo & "Ovoides Lusitanas" & Lusitânia & 16,6 \\
\hline 2562 & 2005 & 9 & 15 & Fase 2 & Bordo & "Ovoides Lusitanas" & Lusitânia & 15,2 \\
\hline 2619 & 2005 & 10 & 4 & Fase 2 & Bordo & "Ovoides Lusitanas" & Lusitânia & 16,4 \\
\hline 2626 & 2005 & 10 & 4 & Fase 2 & Bordo & "Ovoides Lusitanas" & Lusitânia & 15,2 \\
\hline 2652 & 2005 & 10 & 6 & Fase 2 & Bordo & "Ovoides Lusitanas" & Lusitânia & 15,1 \\
\hline 4754 & 2005 & 9 & $9 \mathrm{~b}$ & Fase 2 & Bordo & T-9.1.1.1. - CCNN & Baía gaditana & 19,4 \\
\hline 709 & 2006 & 11 & 6 & Fase 2 & Bordo & Dressel 1 & Guadalquivir & 16,4 \\
\hline 2615 & 2005 & 10 & 4 & Fase 2 & Bordo & Dressel 1 & Itálica & 16,9 \\
\hline 2645 & 2005 & 10 & 4 & Fase 2 & Bordo & Dressel 1 & Itálica & 15,3 \\
\hline 2603 & 2005 & 10 & 4 & Fase 2 & Bordo & Dressel 12 & Guadalquivir & 14,8 \\
\hline 707 & 2006 & 11 & 6 & Fase 2 & Bordo & Dressel 20 & Guadalquivir & 14,4 \\
\hline 735 & 2006 & 11 & 9 & Fase 2 & Bordo & Dressel 20 & Guadalquivir & 17 \\
\hline 2494 & 2005 & 9 & 4 & Fase 2 & Bordo & Dressel 20 & Guadalquivir & 16 \\
\hline 2552 & 2005 & 9 & 12 & Fase 2 & Bordo & Dressel 20 & Guadalquivir & 14,2 \\
\hline 2624 & 2005 & 10 & 4 & Fase 2 & Bordo & Dressel 20 & Guadalquivir & 15,2 \\
\hline 2632 & 2005 & 10 & 4 & Fase 2 & Bordo & Dressel 20 & Guadalquivir & 14,8 \\
\hline 708 & 2006 & 11 & 6 & Fase 2 & Bordo & Dressel 2-4 & Guadalquivir & 15 \\
\hline 715 & 2006 & 11 & $6 \mathrm{a}$ & Fase 2 & Bordo & Dressel 7-11 & Bética costeira & 20 \\
\hline 725 & 2006 & 11 & $7 \mathrm{a}$ & Fase 2 & Bordo & Dressel 7-11 & Bética costeira & 20,4 \\
\hline 833 & 2006 & 10 & 7 & Fase 2 & Bordo & Dressel 7-11 & Bética costeira & 18,6 \\
\hline 2521 & 2005 & 9 & 9 & Fase 2 & Bordo & Dressel 7-11 & Bética costeira & 20,2 \\
\hline 2538 & 2005 & 9 & 10 & Fase 2 & Bordo & Dressel 7-11 & Bética costeira & 18,8 \\
\hline 2549 & 2005 & 9 & 12 & Fase 2 & Bordo & Dressel 7-11 & Bética costeira & 20,8 \\
\hline 2634 & 2005 & 10 & 4 & Fase 2 & Bordo & Dressel 7-11 & Bética costeira & 21 \\
\hline 840 & 2006 & 11 & $6 a$ & Fase 2 & Bordo & Greco-itálica & Itálica & $>17,6$ \\
\hline 2517 & 2005 & 9 & 8 & Fase 2 & Bordo & Greco-Itálica & Itálica & 15,2 \\
\hline 2536 & 2005 & 9 & $9 b$ & Fase 2 & Bordo & Greco-Itálica & Itálica & 18,6 \\
\hline 2617 & 2005 & 10 & 4 & Fase 2 & Bordo & Greco-itálica & Itálica & 20 \\
\hline 2529 & 2005 & 9 & $9 b$ & Fase 2 & Bordo & Greco-Itálica Hispânica & Baía gaditana & 17 \\
\hline 745 & 2006 & 11 & 11 & Fase 2 & Bordo & Haltern 70 & Guadalquivir & 18 \\
\hline 773 & 2006 & 11 & 13 & Fase 2 & Bordo & Haltern 70 & Guadalquivir & 17,5 \\
\hline 780 & 2006 & 11 & 15 & Fase 2 & Bordo & Haltern 70 & Guadalquivir & 15 \\
\hline 781 & 2006 & 11 & 15 & Fase 2 & Bordo & Haltern 70 & Guadalquivir & 15 \\
\hline
\end{tabular}

continúa 


\begin{tabular}{|c|c|c|c|c|c|c|c|c|}
\hline $\mathrm{N}^{\mathrm{o}}$ Inv. & Ano & Vala & Camada & Fase & Fragmento & Tipologia & Produção & Diâmetro bordo \\
\hline 782 & 2006 & 11 & 15 & Fase 2 & Bordo & Haltern 70 & Guadalquivir & 17,7 \\
\hline 836 & 2006 & 11 & 7 & Fase 2 & Bordo & Haltern 70 & Guadalquivir & 19,6 \\
\hline 2506 & 2005 & 9 & 6 & Fase 2 & Bordo & Haltern 70 & Guadalquivir & 16,1 \\
\hline 2507 & 2005 & 9 & 6 & Fase 2 & Bordo & Haltern 70 & Guadalquivir & 15,5 \\
\hline 2527 & 2005 & 9 & $9 b$ & Fase 2 & Bordo & Haltern 70 & Guadalquivir & 14,8 \\
\hline 2533 & 2005 & 9 & $9 b$ & Fase 2 & Bordo & Haltern 70 & Guadalquivir & 16 \\
\hline 2540 & 2005 & 9 & 11 & Fase 2 & Bordo & Haltern 70 & Guadalquivir & 15,8 \\
\hline 2556 & 2005 & 9 & 13 & Fase 2 & Bordo & Haltern 70 & Guadalquivir & 15,5 \\
\hline 2610 & 2005 & 10 & 4 & Fase 2 & Bordo & Haltern 70 & Guadalquivir & 15,6 \\
\hline 2633 & 2005 & 10 & 4 & Fase 2 & Bordo & Haltern 70 & Guadalquivir & 16,6 \\
\hline 2638 & 2005 & 10 & 4 & Fase 2 & Bordo & Haltern 70 & Guadalquivir & 15,6 \\
\hline 2647 & 2005 & 10 & 5 & Fase 2 & Bordo & Haltern 70 & Guadalquivir & 17,6 \\
\hline 713 & 2006 & 11 & $6 a$ & Fase 2 & Bordo & Mañá C2 - T-7.4.3.3. & Baía gaditana & 23,4 \\
\hline 714 & 2006 & 11 & $6 \mathrm{a}$ & Fase 2 & Bordo & Mañá C2 - T-7.4.3.3. & Baía gaditana & 23,8 \\
\hline 718 & 2006 & 11 & 7 & Fase 2 & Bordo & Mañá C2 - T-7.4.3.3. & Baía gaditana & 27 \\
\hline 784 & 2006 & 11 & 15 & Fase 2 & Bordo & Mañá C2 - T-7.4.3.3. & Baía gaditana & 23,6 \\
\hline 785 & 2006 & 11 & 15 & Fase 2 & Bordo & Mañá C2 - T-7.4.3.3. & Baía gaditana & 24,6 \\
\hline 2498 & 2005 & 9 & 5 & Fase 2 & Bordo & Mañá C2 - T-7.4.3.3. & Baía gaditana & 23,4 \\
\hline 2516 & 2005 & 9 & 7 & Fase 2 & Bordo & Mañá C2 - T-7.4.3.3. & Baía gaditana & 27,6 \\
\hline 2522 & 2005 & 9 & $9 b$ & Fase 2 & Bordo & Mañá C2 - T-7.4.3.3. & Baía gaditana & 27,2 \\
\hline 2601 & 2005 & 10 & 3 & Fase 2 & Bordo & Mañá C2 - T-7.4.3.3. & Baía gaditana & 25,4 \\
\hline 2657 & 2005 & 10 & $6 a$ & Fase 2 & Bordo & Mañá C2 - T-7.4.3.3. & Baía gaditana & 23,4 \\
\hline 2661 & 2005 & 10 & 7 & Fase 2 & Bordo & Mañá C2 - T-7.4.3.3. & Baía gaditana & 23,8 \\
\hline 743 & 2006 & 11 & 10 & Fase 2 & Bordo & Oberaden 83 & Guadalquivir & 12,8 \\
\hline 772 & 2006 & 11 & 13 & Fase 2 & Bordo & Oberaden 83 & Guadalquivir & 13,6 \\
\hline 774 & 2006 & 11 & 13 & Fase 2 & Bordo & Oberaden 83 & Guadalquivir & 14,6 \\
\hline 2508 & 2005 & 9 & 6 & Fase 2 & Bordo & Oberaden 83 & Guadalquivir & 15,4 \\
\hline 2518 & 2005 & 9 & 8 & Fase 2 & Bordo & Oberaden 83 & Guadalquivir & 15,4 \\
\hline 2523 & 2005 & 9 & $9 b$ & Fase 2 & Bordo & Oberaden 83 & Guadalquivir & 13,2 \\
\hline 2526 & 2005 & 9 & $9 b$ & Fase 2 & Bordo & Oberaden 83 & Guadalquivir & 13,8 \\
\hline 2537 & 2005 & 9 & 10 & Fase 2 & Bordo & Oberaden 83 & Guadalquivir & 13,8 \\
\hline 2558 & 2005 & 9 & 13 & Fase 2 & Bordo & Oberaden 83 & Guadalquivir & 14,2 \\
\hline 2563 & 2005 & 9 & 15 & Fase 2 & Bordo & Oberaden 83 & Guadalquivir & 15 \\
\hline 2659 & 2005 & 10 & 7 & Fase 2 & Bordo & Oberaden 83 & Guadalquivir & 16,4 \\
\hline 2500 & 2005 & 9 & 6 & Fase 2 & Bordo & Verulamium 1908 & Guadalquivir & 14,6 \\
\hline 2510 & 2005 & 9 & 6 & Fase 2 & Bordo & Verulamium 1908 & Guadalquivir & 17 \\
\hline
\end{tabular}


os contextos arqueológicos -, traçar um esboço do que seriam os hábitos de consumo em Olisipo durante o período de tempo que se estende desde a segunda metade do século II a.C. até ao terceiro quartel do século I d.C., particularmente entre o principado de Augusto e o de Nero. Estas considerações deverão ser entendidas enquanto propostas de trabalho.

Adicionalmente, os estudos recentemente desenvolvidos, versando sobre amplos conjuntos anfóricos de sítios com ocupações em análogos horizontes culturais e cronológicos (Morais 1998 e 2005; Pimenta 2005; Almeida 2008; Bargão 2006), provêem-nos de bons paralelos para a área do ocidente peninsular, sobretudo para a região do vale do Tejo - Lisboa e Santarém -, permitindo que se estabeleçam comparações quanto aos diversos aspectos informativos inerentes ao estudo destes contentores.

Face ao que se conhece, creio que os dados do teatro romano se podem, de um modo geral, extrapolar à cidade de Olisipo no que se refere aos ritmos de consumo e fluxos de importação durante o espaço de tempo que decorre entre o principado de Augusto e o de Nero. Porém, a expressão quantitativa do conjunto anfórico em estudo, embora se possa considerar de "fiabilidade aceitável” (Molina Vidal 1997: 47), não é suficientemente representativa, pelo que, naturalmente, carecerá sempre de ser confirmada através dos dados de outras intervenções e do estudo de outros conjuntos anfóricos.

Nesta óptica, os resultados das recentes intervenções arqueológicas levadas a cabo no teatro romano de Lisboa revestem-se de particular importância na caracterização dos diferentes ritmos de ocupação da urbe romana, quer no que se refere à sua dinâmica comercial, quer no que diz respeito especificamente ao momento de construção daquele importante edifício público - estas intervenções permitiram, pela primeira vez, escavar níveis directamente relacionados com a construção do teatro. A documentação de um volumoso conjunto de materiais associados a contextos estratigráficos, diacronicamente bem circunscritos entre o principado de $\mathrm{Au}$ gusto e o de Nero, permite colmatar em certa medida a latente escassez de informação que se observa relativamente a esta fase da ocupação romana em Olisipo.

Os contextos de época romana escavados no decurso destas intervenções relacionam-se, numa primeira fase, com a construção do teatro, que parece ter ocorrido durante os finais do principado de Augusto ou inícios de Tibério, e numa segunda com as obras de remodelação que o edifício sofreu em 57 d.C. Os referidos contextos constituem-se principalmente como níveis de aterro, aparentemente efectuados após as referidas obras. Porém, as vicissitudes relativas à formação destes depósitos, a que certamente não estarão alheias as profundas intrusões no subsolo que as obras de construção do teatro terão provocado, lograram que se preservasse nestes contextos, embora em clara deposição secundária, um numeroso conjunto de materiais de fases mais recuadas, nomeadamente de cronologia republicana e da Idade do Ferro, cujo valor informativo não é, de todo, despiciendo. Tendo em conta a importância e pertinência dessa informação - no caso vertente, concretamente aquela que diz respeito às ânforas de época republicana -, esses dados foram incluídos na análise quantitativa e qualitativa, devendo, contudo, ser devidamente matizados.

No que aos materiais de época republicana se refere, os elementos do teatro romano reportam-nos sobretudo à segunda metade do século II a.C., observando-se principalmente a presença de materiais importados da Península Itálica e da Baía Gaditana e, em menor escala, do Norte de África. A presença de ânforas de tipo Greco-Itálico tardias, Greco-Itálicas de produção hispânica, Dressel 1 de transição, Tripolitana Antiga, T-9.1.1.1. e as Mañá C2 (T-7.4.3.1. e T-7.4.3.3.), documentam incontestavelmente um momento precoce da presença romana em Olisipo e no ocidente peninsular, enquadrável no mesmo âmbito cronológico dos contextos republicanos mais antigos da colina do castelo, atribuídos por João Pimenta (2005) ao período entre 140-130 a.C., e relacionados com a campanha militar encetada por Décimo Júnio Bruto em 138 a.C..

Contrariamente ao que sucede no castelo de São Jorge (idem), em Santarém (Arruda e Almeida 1998 e 1999; Bargão 2006) e em Chões de Alpompé (Diogo 1982; Fabião 1989; Diogo e Trindade 1993-94) - embora este último local nunca tenha sido intervencionado arqueologicamente -, não se observa nas ânforas republicanas do teatro romano a usual supremacia da forma Dressel 1 e dos vinhos itálicos sobre os outros produtos, registando-se inclusivamente um maior número de Greco-Itálicas em relação àquela tipologia. A efectiva maior representatividade das ânforas piscícolas gaditanas Mañá C2 (T-7.4.3.3.) não pode apenas ser explicada pela sua maior longevidade de produção, uma vez que o mesmo se verifica com os contentores vinários itálicos Dressel 1. Poder-se-á procurar no tipo de ocupação documentada naqueles locais e no facto de se terem escavado contextos preservados daquela época, uma explicação para os dados do teatro, não deixando, contudo, de ter presente a especificidade dos contextos que aqui se analisam, e a possibilidade de tal se dever a um qualquer factor meramente circunstancial. De 
qualquer forma, com excepção do azeite itálico da região de Brindes, ausente no conjunto do teatro romano, regista-se a presença dos mesmos produtos, importados das mesmas regiões produtoras e no mesmo tipo de contentores daqueles que se observam em Santarém, Chões de Alpompé e castelo de São Jorge, bem como de alguns locais do Algarve, recentemente sintetizados (Bargão 2006).

Tanto as importações de vinho itálico como as de preparados piscícolas da região meridional hispânica, tal como, ao que tudo indica, o azeite africano, inscrevem-se no âmbito de uma rede de abastecimento público ao exército (Fabião 1989; Pascual Berlanga e Ribera i Lacomba 2002; Pimenta 2005; Bargão 2006). Terá sido nesse contexto de aprovisionamento alimentar aos contingentes militares que esses produtos chegaram ao extremo ocidente peninsular.

O significativo aumento das importações béticas que se constata na generalidade dos sítios no ocidente peninsular a partir de meados do século I a.C., visível, por exemplo, em Braga (Morais 1998 e 2005), na Lomba do Canho (Fabião 1989), em Santarém (Arruda e Almeida 1999 e 2000; Arruda et al. 2005; Almeida 2008; Bargão 2006) e no conjunto do teatro romano, parece constituir-se como um indicador da "progressiva ascensão económica da Península Ibérica” (Fabião 1989: 121) que se deve, sobretudo, a um "substancial incremento da produção vitivinícola” (Fabião 1998b: 182).

Paralelamente, a importação do vinho tirrénico transportado em ânforas de tipo Dressel 1 Itálica vai diminuindo, até desaparecer completamente, durante a segunda metade do século I a.C., não se visualizando, nos conjuntos anfóricos do ocidente peninsular, uma efectiva substituição desses contentores pelas suas sucessoras Dressel 2-4. De facto, a escassa representação desta última tipologia no conjunto do teatro (apenas um exemplar de fabrico itálico) verifica-se também em outros locais do actual território português, como por exemplo em Santarém (Arruda e Almeida 2000). Do mesmo modo, a presença de vinho itálico da costa adriática, transportado em ânforas de tipo Lamboglia 2, durante o século I a.C. é claramente minoritária. (Figura 20).

Assim, a partir da segunda metade do século I a.C. prevalece aquilo que Carlos Fabião designou de "princípio da proximidade geográfica nos critérios de importação" (Fabião 1998b: 181), consubstanciada na preponderância que as importações da região meridional hispânica adquirem a partir deste período na generalidade dos locais que se estendem um pouco por toda a fachada atlântica.
A informação que o conjunto anfórico do teatro romano permite apreender, demonstra um notável incremento na importação de bens alimentares, traduzida numa significativa importação principalmente de vinho e azeite bético a partir do principado de Augusto, sobretudo em ânforas de tipo Haltern 70 e Oberaden 83, que supera as importações de preparados piscícolas provenientes da mesma província, principalmente efectuado em ânforas de tipo Dressel 7-11. Esta evidência não parece ser totalmente verificada em Santarém durante o mesmo período, onde se destaca claramente a importação do vinho sobre os outros produtos e onde o azeite, embora bastante representativo, é importado em menores quantidades que os preparados piscícolas (Arruda et al. 2005; Almeida 2008).

Os dados do teatro romano contribuem para confirmar - se é que tal ainda se afigura necessário - a existência de uma rede de abastecimento regular de carácter institucional, que, com origem na província da Bética e transportando os produtos alimentares ali produzidos, percorreria toda a fachada ocidental da Península Ibérica, alcançando os estabelecimentos mais setentrionais do limes germânico e, posteriormente, da Britannia. Certamente, será a esta rota atlântica, destinada sobretudo a aprovisionar os contingentes militares estacionados no noroeste peninsular e no limes (Morais e Carreras Monfort 2003), que se deve o significativo fluxo de vinho e azeite bético verificado no teatro romano de Olisipo e em locais como Scallabis e Bracara Augusta a partir do principado de Augusto.

A marca L. HOR registada no teatro romano de Lisboa e a presença de marcas relacionáveis em locais como Scallabis e noroeste peninsular (Almeida 2008: 291), contribui para enfatizar o que atrás se referiu.

A diminuição, face ao período precedente, das importações de preparados piscícolas béticos a partir dos finais do principado de Augusto parece estar, no caso concreto do teatro romano, directamente relacionada com a emergência das produções piscícolas lusitanas, que adquirem a partir de então uma expressão quantitativa bastante significativa. De facto, embora tal cenário não deixe de ser admissível numa perspectiva mais ampla, não se pode deixar de referir que em Santarém não se verifica análoga situação (Arruda et al. 2005 e 2006; Almeida 2008). Embora as típicas ânforas piscícolas deste período - Dressel 7-11 - não alcancem o volume de importação que as Mañá C2 anteriormente alcançaram naquela cidade, elas são mais numerosas que as produções lusitanas antigas, estando presentes em proporções muito superiores às que se registam no teatro romano de Lisboa. Tendo em conta que os dados 


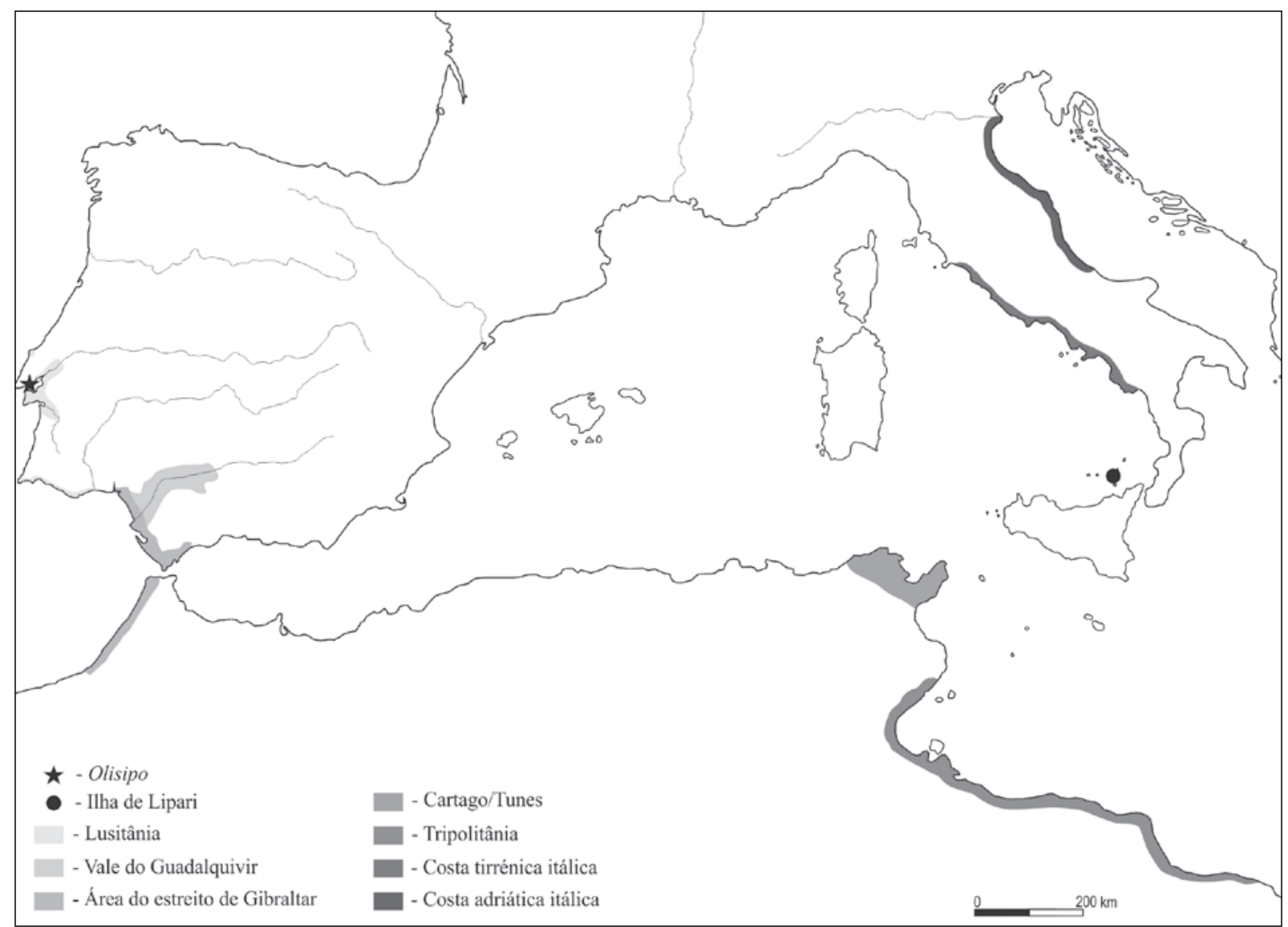

Figura 20. Localização das diferentes regiões produtoras de ânforas presentes no teatro romano de Lisboa (modificado a partir de Ramon Torres 1995). Localizações aproximadas.

globais de Santarém têm uma representação quantitativa bastante superior aos do teatro, terá sempre que se olhar com precaução para o significado quantitativo do conjunto aqui em análise, sob pena de indevidamente se extrapolar para outros contextos uma realidade que, hipoteticamente, apenas aqui se verifica. De qualquer modo, não deixa de ser curioso que na intervenção da rua dos Bacalhoeiros (Fernandes et al. 2006; Filipe 2008) se documente, também, uma superioridade numérica bastante acentuada das ânforas lusitanas face às de origem bética, no que se refere aos recipientes piscícolas, em contextos do primeiro/inícios do segundo quartel do século I d.C.

Relativamente à fase final da ocupação deste espaço, terceiro quartel do século I d.C., observa-se a continuidade do abastecimento de produtos originários da Bética, nomeadamente de azeite, através das ânforas Dressel 20, e vinho, presente nas variantes mais tardias de Haltern 70 e nas Verulamium 1908 e possivelmente também nas Dressel 28, ânforas de tipo
Urceus e Dressel 2-4 Hispânicas. Quanto aos preparados à base de peixe, poderão estar representados por algumas variantes do tipo Dressel 7-11 béticas e Ovoides Lusitanas. De qualquer forma, estes materiais mais tardios parecem ser quantitativamente menos representativos que os da fase anterior, podendo isso, eventualmente, indiciar, ainda durante o terceiro quartel da primeira centúria d.C., a diminuição global da importação de produtos alimentares da província da Bética, registada em Santarém sobretudo a partir do último quartel desse século.

\section{Agradecimentos}

Não posso deixar de agradecer ao Professor Carlos Fabião (Faculdade de Letras da Universidade de Lisboa), orientador da minha dissertação de mestrado, que me mostrou o "mundo das ânforas" e que desde cedo me incentivou na realização deste projecto. À Dr. ${ }^{a}$ 
Lídia Fernandes (Museu do Teatro Romano de Lisboa, CML) devo a oportunidade de estudar o conjunto anfórico do teatro romano e o incansável acompanhamento que, desde o primeiro ao último dia, lhe dedicou. Ao Dr. João Pimenta (Câmara Municipal de Vila Franca de Xira) a possibilidade de observar as pastas das ânforas do Castelo de São Jorge e compará-las com as do teatro. Ao Marco Calado pela ajuda na triagem dos materiais distribuídos por incontáveis contentores. E finalmente à Anabela de Castro, por significar parte deste trabalho.

\section{BIBLIOGRAFIA}

Alarcão, J. (1994): "Lisboa romana e visigótica", in Lisboa subterrânea: 58-63. Lisboa, Lisboa Capital Europeia da Cultura 94.

Almeida, F. (1966): "Notícias sobre o teatro de Nero, em Lisboa". Lucerna 5: 561-571.

Almeida, R. (2008): Las Ánforas del Guadalquivir en Scallabis (Santarém, Portugal). Una aportación al conocimiento de los tipos minoritarios. Col.lecció Instrumenta, 28. Barcelona, Universidad de Barcelona.

Amaro, C. (1993): "Vestígios materiais orientalizantes do claustro da Sé de Lisboa". Estudos Orientais IV - Os Fenícios no território Português: 183-192. Lisboa, Instituto Oriental da Universidade Nova de Lisboa.

Amaro, C. (1995): Núcleo arqueológico da Rua dos Correeiros. Lisboa, Fundação Banco Comercial Português.

Amaro, C. (2002): "Percurso arqueológico através da Casa dos Bicos", in C. Amaro e T. Miranda (Coords.), De Olisipo a Lisboa. A casa dos Bicos: 11-27. Lisboa, Comissão Nacional para as Comemorações dos Descobrimentos Portugueses.

Angelucci, D.; Costa, C. e Muralha, J. (2004): “Ocupação neolítica e pedogénese médio-holocénica na Encosta de Sant'Ana (Lisboa): considerações geoarqueológicas". Revista Portuguesa de Arqueologia 7:2: 27-47.

Arcelin, P. e Tuffreau-Libre, M. (1998): La quantification des céramiques: conditions et protocole. Actes de la table ronde du centre archéologique européen do Mont Beuvray. Collection Bibracte, 2. Glux-enGlenne (1998). Glux-en-Glenne, Centre Archéologique Européen du Mont Beuvray.

Arruda, A. M. (2002): Los Fenicios en Portugal. Fenicios y mundo indígena en el centro y sur de Portugal (siglos VIII-VI a.C.). Cuadernos de Arqueología Mediterránea. 5-6. Barcelona, Universitat Pompeu Fabra.
Arruda, A. M. e Almeida, R. (1998): “As ânforas da Classe 32 da Alcáçova de Santarém (Campanhas de 1983-1991)". Conímbriga 37: 201-231.

Arruda, A. M. e Almeida, R. (1999): “As importações de vinho itálico para o território actualmente português: contextos, cronologias e significado", in Économie et territoire en Lusitanie romaine: 307-337. Madrid, Casa de Vélazquez.

Arruda, A. M. e Almeida, R. (2000): “Importação e consumo de vinho bético na colónia Romana da Scallabis (Santarém, Portugal)", in Actas Congreso Internacional Ex Baetica Amphorae. Conservas y vino de la Bética en el Imperio Romano: 703-715. Vol. 2. Écija, Gráficas Sol.

Arruda, A. M.; Freitas, V. T. e Vallejo Sánchez, J. I. (2000): "As cerâmicas cinzentas da Sé de Lisboa". Revista Portuguesa de Arqueologia 3:2: 25-59.

Arruda, A. M.; Viegas, C. e Bargão, P. (2005): "As ânforas da Bética costeira na Alcáçova de Santarém”. Revista Portuguesa de Arqueologia 8:1: 279-297.

Arruda, A. M.; Viegas, C. e Bargão, P. (2006): "Ânforas lusitanas da Alcáçova de Santarém”, in Simpósio Internacional Produção e comércio de preparados piscícolas durante a Proto-História e a época Romana no Ocidente da Península Ibérica. Homenagem a Françoise Mayet. Setúbal Arqueológica, 13: 233-252. Setúbal, Museu de Arqueologia e Etnografia do Distrito de Setúbal.

Bargão, P. (2006): As importações anfóricas do Mediterrâneo durante a época Romana Republicana na Alcáçova de Santarém. Dissertação de Mestrado em Pré-história e Arqueologia, apresentado à Faculdade de Letras da Universidade de Lisboa. Lisboa. Inédito.

Beltrán Lloris, M. (1970): Las ánforas romanas de España. Zaragoza, Institución Fernando el Católico.

Benquet, L. e Olmer, F. (2002): « Les amphores », in La Loba (Fuenteobejuna, Cordoue, Espagne). La mine et le village minier antiques : 295-331. Bordeaux, Ausonius (Mémoires 7).

Bernal Casasola, D.; Roldán Gómez, L.; Blánquez Pérez, J.; Díaz Rodríguez, J. e Prados Martínez, F. (2004): "Las Dr. 2-4 béticas. Primeras evidencias de su manufactura en el Conventus Gaditanus", In Actas del Congreso Internacional Figlinae Baeticae. Talleres Alfareros y Producciones Cerámicas en la Bética Romana (ss. II a.C. - VII d.C.). B.A.R. International Series, 1266: 633-648. Oxford, John and Erica Hedges Ltd.

Berni Millet, P. (1998): Las ánforas de aceite de la Bética y su presencia en la Cataluña Romana. Col.lecció Instrumenta 4. Barcelona, Universitat de Barcelona. 
Borgard, P. (1994): “L'origine liparote des amphores "Richborough 527" et la détermination de leur contenu", in Actes du Congrès de Millau, 12-15 Mai 1994 : 197-203. Millau (1994), Marseille, Société Française d'Étude de la Céramique Antique en Gaule.

Borgard, P. (2005): "Les amphores à alun (Ier siècle avant J.-C. - IVe siècle après J.-C.) ", in L'Alun de Méditerranée, Colloque International: 157-169. Collection du Centre Jean Bérard, 23. Naples/Aixen-Provence, Centre Jean Bérard.

Bugalhão, J. (2001): A indústria romana de transformação e conserva de peixe em Olisipo. Núcleo Arqueológico da Rua dos Correeiros. Trabalhos de Arqueologia, 15. Lisboa, Instituto Português de Arqueologia.

Buraca, I. (2005): Civitas Conímbriga: Ânforas romanas. Dissertação de Mestrado em Arqueologia, na área de especialização em Arqueologia Regional, apresentado à Faculdade de Letras da Universidade de Coimbra. Coimbra. Inédito.

Cipriano, M. T. e Carre, M. B. (1989): "Production et typologie des amphores sur la côte adriatique de l'Italie", in Amphores romaines et histoire économique: Dix ans de recherche. Collection de l'École Française de Rome, 114: 67-104. Roma, École Française de Rome.

Comas i Sola M. (1997): Baetulo. Les marques d'àmfora. Barcelona, Institut d'Estudis Catalans.

De Nicolas J. C. (1979): "Epigrafía anforaria de Menorca". Revista de Menorca 70: 5-80.

Desbat, A. (1998): "L'arrêt des importations de Dressel 1 en Gaule", in Actes du Congrès d'Istres : 31-35. Istres (1998), Marseille, Société Française d'Étude de la Céramique Antique en Gaule.

Diogo, A. M. D. (1982): “A propósito de «Moron». Estudo de alguns documentos provenientes dos Chões de Alpompé (Santarém)". Clio 4: 147-154.

Diogo, A. M. D. (1993): “O teatro romano de Lisboa. Notícia sobre as actuais escavações", in Teatros Romanos de Hispania. Cuadernos de Arquitectura Romana, 2: 217-224. Múrcia.

Diogo, A. M. D. (2000): “As ânforas das escavações de 1989-93 do Teatro Romano de Lisboa”. Revista Portuguesa de Arqueologia 3:1: 163-179.

Diogo, A. M. D. e Sepúlveda, E. (2000): “As lucernas das escavações de 1989/93 do teatro romano de Lisboa”. Revista Portuguesa de Arqueologia 3: 1:153-161.

Diogo, A. M. D. e Trindade, L. (1993-94): "Materiais provenientes de Chões de Alpompé (Santarém)". Conímbriga 32-33: 263-281.

Espírito Santo, A. (2004): “Textos relativos às guerras lusitanas, as presenças invisíveis”, in Medina (Dir.)
História de Portugal, Vol. II, pp. 412-413. Lisboa, Ediclube.

Fabião, C. (1987): “Ânforas romanas republicanas de um depósito de Mértola no Museu Nacional de Arqueologia e Etnologia". O Arqueólogo Português Série IV, 5: 125-148.

Fabião, C. (1989): Sobre as ânforas do acampamento romano da Lomba do Canho (Arganil). Lisboa, UNIARQ / INIC.

Fabião, C. (1993): "O passado Proto-Histórico e Romano", In J. Mattoso (coord.), História de Portugal, Vol. I: 77-201. Lisboa, Círculo de Leitores.

Fabião, C. (1998a): O Mundo indígena e a sua romanização na área céltica do território hoje português. Dissertação de Doutoramento em Arqueologia apresentada à Faculdade de Letras da Universidade de Lisboa. Lisboa. Policopiado.

Fabião, C. (1998b): “O vinho na Lusitânia: reflexões em torno de um problema arqueológico". Revista Portuguesa de Arqueologia 1:1: 169-198.

Fabião, C. (2000): "Sobre as mais antigas ânforas «romanas» da Baetica no ocidente peninsular", in Actas Congreso Internacional Ex Baetica Amphorae. Conservas y vino de la Bética en el Imperio Romano Vol. 2: 665-682. Écija, Gráficas Sol.

Fabião, C. (2006): A Herança Romana em Portugal. Clube do Coleccionador dos Correios, CTT Correios de Portugal.

Fabião, C. (2008): "Las ánforas de Lusitania", in D. Bernal Casasola \& A. Ribera i Lacomba (eds.), Cerámicas hispanorromanas. Un estado de la cuestión: 725-745. Cádiz, Universidad de Cádiz.

Fabião, C. e Guerra, A. (1994): "As ocupações antigas de Mesas do Castelinho (Almodôvar). Resultados preliminares das campanhas de 1990-92", in Actas das V Jornadas Arqueológicas da Associação dos Arqueólogos Portugueses: 275-290. Lisboa (1993), Lisboa, Associação dos Arqueólogos Portugueses.

Faria, A. M. (1999): “Colonização e municipalização nas províncias hispano-romanas: reanálise de alguns casos polémicos". Revista Portuguesa de Arqueologia 2:2: 29-50.

Fernandes, L. (1997): Capitéis romanos da Lusitânia ocidental. Dissertação de Mestrado em Historia de Arte apresentada à Faculdade de Ciências Sociais e Humanas da Universidade Nova de Lisboa. Lisboa. Policopiado.

Fernandes, L. (2006): "O teatro de Lisboa. Intervenção arqueológica de 2001", in Jornadas sobre teatros romanos en Hispania. Actas del Congreso 
Internacional: 181-204. Córdoba (2002), Córdoba, Seminario de Arqueología.

Fernandes, L. (2007): “Teatro romano de Lisboa - os caminhos da descoberta e os percursos de investigação arqueológica". Al-Madan, II ${ }^{\mathrm{a}}$ série, 15: 28-39.

Fernandes, L. (2008): “As bases de coluna nos desenhos dos séculos XVIII e XIX do teatro romano de Lisboa". Revista da Associação dos Arqueólogos Portugueses 56-57: 83-94.

Fernandes, L. e Filipe, V. (2007): "Cerâmicas de engobe vermelho pompeiano do teatro romano de Lisboa". Revista Portuguesa de Arqueologia 10:2: 229-253.

Fernandes, L.; Marques, A.; Filipe, V. e Calado, M. (2006): "Núcleo de transformação piscícola de época romana na Rua dos Bacalhoeiros (Lisboa)", in Simpósio A Costa Portuguesa no Panorama da Rota Atlântica Durante a Época Romana. Peniche (2006), no prelo.

Filipe, V. (2008): "Importação e exportação de produtos alimentares em Olisipo: as ânforas romanas da Rua dos Bacalhoeiros". Revista Portuguesa de Arqueologia 11:2: 301-324.

Filipe, V.; Calado, M. e Leitão, M. (2014): "Evidências orientalizantes na área urbana de Lisboa: o caso dos edifícios na envolvente da Mãe de Água do Chafariz d'El Rei", in VI Congresso Internacional de Estudos Fenícios e Púnicos. Lisboa (2005): 736-746.

Fontes, J. (1947): “A Proto-história", in Lisboa: Oito séculos de História: 56-65. Lisboa, Câmara Municipal.

García Vargas, E. (2004): “Las ánforas del vino bético altoimperial: formas, contenidos y alfares a la luz de algunas novedades arqueológicas", in Actas del Congreso Internacional Figlinae Baeticae. Talleres Alfareros y Producciones Cerâmicas en la Bética Romana (ss. II a.C - VII d.C.). B.A.R. International Series, 1266: 507-514. Oxford, John and Erica Hedges Ltd.

García Vargas, E.; Almeida, R. e González Cesteros, H. (2011): "Los tipos anfóricos del Guadalquivir en el marco de los envases hispanos del siglo I a.C. Un universo heterogéneo entre la imitación y la estandarización”. Spal 20: 185-283. http://dx.doi. org/10.12795/spal.2011.i20.12.

Gaspar, J. (1994): “O desenvolvimento do sítio de Lisboa", in I. Moita (coord.), O Livro de Lisboa: 1124. Lisboa.

Gateau, F. (1990) : “Amphores importées durant le le IIe s. av. J.C. dans trois habitats de Provence occidentale: Entremont, le Baou-Roux, Saint-Blaise". Documents d'Archéologie Méridionale 13: 163-183.
Gomes, A.; Gaspar, A.; Pimenta, J.; Guerra, S.; Mendes, H.; Ribeiro, S.; Valongo, A. e Pinto, P. (2003): "Castelo de São Jorge - Balanço e perspectivas dos trabalhos arqueológicos”. Património Estudos 4: 214-223.

Guerra, A. (2000): “A península de Lisboa no I milénio a.C. uma breve síntese, à luz das fontes e dos dados arqueológicos", in TURRES VETERAS IV. Actas de Pré-história e História Antiga: 121-128. Torres Vedras, Câmara Municipal de Torres Vedras.

Hauschild, T. (1990): "Das römishe Theater von Lissabon. Planaufnhame 1985/88". Madrider Mitteilungen 31: 348-392.

Hesnard, A. e Lemoine, C. (1981): "Les amphores du Cécube et du Falerne: prospection, typologie et analyses". Mélanges de l'École Française de Rome-Antiquité 93: 243-295.

Hesnard, A.; Monique, R.; Arthur, P.; Picon, M. e Tchernia, A. (1989): “Aires de production des gréco-italiques et des Dr. 1", In Amphores romaines et histoire économique: Dix ans de recherche. Collection de l'École Française de Rome, 114: 21-65. Rome, École Française de Rome.

Hidalgo Cuñarro, J. M. (1987): "Materiales arqueológicos del Castro de Vigo". Lucentum 6: 123-134.

Le Roux, P. (1995): Romains d'Espagne: Cités \& Politique dans les Provinces: IIe siècle av. J.-C. - IIIe siècle ap. J.-C. Paris, Armand Colin.

Márquez Villora J. C. e Molina Vidal J. (2001): El comercio en el territorio de Ilici. Epigrafia, importación de alimentos y relación con los mercados mediterráneos. Alicante, Publicaciones de la Universidad de Alicante.

Mayet, F. e Silva, C. T. (1998): L'atelier d'amphores de Pinheiro. Portugal. Paris, De Boccard.

Mayet, F. e Silva, C. T. (2002): L'atelier d'amphores d'Abul. Paris, De Boccard.

Moita, I. (1970): "O teatro romano de Lisboa". Revista Municipal 124/125: 7-37.

Molina Vidal, J. (1997): La dinámica comercial romana entre Italia e Hispania Citerior. Alicante, Instituto de Cultura Juan Gil-Albert.

Morais, R. (1998): As ânforas da zona das Carvalheiras. Braga, Universidade do Minho.

Morais, R. (2003): "Problemàtiques i noves perspectives sobre les àmfores ovóides tardo-republicanes. Les àmfores ovoides de producció Lusitana", in $\mathrm{Cu}$ lip VIII $i$ les àmfores Haltern 70. Monografies del Casc 5: 36-40. Girona.

Morais, R. (2004): "Bracara Augusta: um pequeno "testaccio" de ânforas Haltern 70. Considerações e problemáticas de estudo", in Actas del Congreso 
Internacional Figlinae Baeticae. Talleres Alfareros y Producciones Cerâmicas en la Bética Romana (ss. II a.C - VII d.C.). B.A.R. International Series, 1266: 545-565. Oxford, John and Erica Hedges Ltd.

Morais, R. (2005): Autarcia e Comércio em Bracara Augusta: contribuição para o estudo económico da cidade no período Alto-Imperial. Bracara Augusta, Escavações arqueológicas 2. Braga, Unidade de Arqueologia da Universidade do Minho, Núcleo de Arqueologia da Universidade do Minho.

Morais, R. (2007): “Ânforas tipo Urceus de produção bética e produções regionais e locais do NW peninsular", in Actas del congreso Internacional CETARIAE. Salsas y salazones de pescado en Occidente durante la Antigüedad. B.A.R. International Series 1686: 401-415. Cádiz (2005), Oxford.

Morais, R. e Carreras Monfort, C. (2003): "Geografia del consum de les Haltern 70", in Culip VIII $i$ les àmfores Haltern 70. Monografies del Casc 5: 93112. Girona.

Morais, R. e Fabião, C. (2007): "Novas produções de fabrico lusitano: problemáticas e importância económica", in Actas del congreso Internacional CETARIAE. Salsas y salazones de pescado en Occidente durante la Antigüedad. B.A.R. International Series 1686: 127-133. Cádiz (2005), Oxford.

Muralha, J. (1988): "Carta arqueológica do concelho de Lisboa". Revista Municipal II série, 23: 3-15 e 24: 3-25.

Muralha, J.; Costa, C. e Calado, M. (2002): "Intervenções arqueológicas na encosta de Sant'Ana (Martim Moniz, Lisboa)". Al-Madan 2a Série, 11: 245-246.

Paiva, M. (1993): Anforas romanas de castros da fachada atlântica do Norte de Portugal. Dissertação de Mestrado em Arqueologia apresentada à Faculdade de Letras da Universidade do Porto. Porto. Inédito.

Pascual Berlanga, G. e Ribera i Lacomba, A. (2002): "Las ánforas tripolitanas antiguas en el contexto del Occidente Mediterráneo. Un contenedor poco conocido de la época republicana", in Vivre, produire, échanger: reflets méditerranéens, Mélanges offerts à Bernard Liou. Archéologie et Histoire Romaine 8: 303-318. Montagnac, Monique Mergoil.

Peacock, D. P. S. e Williams, D. F. (1986): Amphorae and the Roman Economy, an Introductory Guide. London, Longman Publications.

Pimenta, J. (2005): As ânforas romanas do Castelo de São Jorge (Lisboa). Trabalhos de Arqueologia, 41. Lisboa, Instituto Português de Arqueologia.
Pimenta, J.; Calado, M. e Leitão, M. (2005): "Novos dados sobre a ocupação pré-romana da cidade de Lisboa: as ânforas da sondagem n. ${ }^{\circ} 2$ da Rua de São João da Praça". Revista Portuguesa de Arqueologia 8(2): 313-334.

Pimenta, J.; Sepúlveda, E.: Faria, J. C. e Ferreira, M. (2006): "Cerâmicas romanas do lado ocidental do castelo de Alcácer do Sal, 4: ânforas de importação e de produção lusitana". Revista Portuguesa de Arqueologia 9(2): 299-316.

Ramón Torres, J. (1995): Las ánforas fenicio-púnicas del Mediterráneo central y occidental. Col.lecció Instrumenta, 2. Barcelona.

Remesal Rodríguez, J. e Carreras Monfort, C. (2003): "Historia de la recerca", in Culip VIII i les àmfores Haltern 70. Monografies del Casc 5: 19- 23. Girona.

Ribeiro, O. (1998): Portugal: o Mediterrâneo e o Atlântico. Colecção «Nova Universidade». Lisboa, Livraria Sá da Costa Editora, $7^{\mathrm{a}}$ Edição.

Sepúlveda, E. e Fernandes, L. (2009): “As marcas em terra sigillata de tipo itálico do teatro romano de Lisboa (campanhas 2005/2006)". Revista Portuguesa de Arqueologia 12(1): 139-168.

Silva, A. (2008): Vivre au-dela du fleuve de l'oubli. Portrait de la communauté villageoise du Castro do Vieito (estuaire do Rio Lima, NO du Portugal), au moment de l'intégration du NO de la péninsule ibérique dans l'orbis romanum. Dissertação de Doutoramento em Arqueologia apresentada à Faculdade de Letras da Universidade de Coimbra. Policopiado.

Silva, C.T. (1996): "Produção de ânforas na área urbana de Setúbal: a oficina romana do Largo da Misericórdia", in Ocupação romana dos estuários do Tejo e do Sado. Actas das Primeiras Jornadas sobre Romanização dos Estuários do Tejo e do Sado: 43-54. Seixal, Câmara Municipal - Lisboa, Dom Quixote.

Silva, R. B. (1999): "Urbanismo de Olisipo: a zona ribeirinha", in Actas do II colóquio temático Lisboa Ribeirinha: 43-67. Lisboa, Câmara Municipal.

Silva, R. B.; Pimenta, J. e Calado, M. (2005): "Sobre a ocupação pré-romana de Olisipo: a I.A.U. da Rua de São Mamede ao Caldas $\mathrm{n}^{\circ} 15$ ", in VI Congresso Internacional de Estudos Fenícios e Púnicos. Lisboa (2005), Lisboa. No prelo.

Silva, V. (1944): Epigrafia de Olisipo (Subsidios para a história da Lisboa Romana). Lisboa, Câmara Municipal.

Tchernia, A. (1986): Le vin de l'Italie romaine. Essai d'histoire économique d'après les amphores. Paris, De Boccard. 